\title{
Stimulation of Adult Oligodendrogenesis by Myelin-Specific T Cells
}

\author{
Helle Hvilsted Nielsen, Henrik Toft-Hansen, \\ Kate Lykke Lambertsen, Trevor Owens, and \\ Bente Finsen
}

From the Institute of Molecular Medicine, University of Southern Denmark, Odense, Denmark

In multiple sclerosis (MS), myelin-specific T cells are normally associated with destruction of myelin and axonal damage. However, in acute MS plaque, remyelination occurs concurrent with T-cell infiltration, which raises the question of whether $T$ cells might stimulate myelin repair. We investigated the effect of myelin-specific $\mathbf{T}$ cells on oligodendrocyte formation at sites of axonal damage in the mouse hippocampal dentate gyrus. Infiltrating $T$ cells specific for myelin proteolipid protein stimulated proliferation of chondroitin sulfate NG2-expressing oligodendrocyte precursor cells early after induction via axonal transection, resulting in a $25 \%$ increase in the numbers of oligodendrocytes. In contrast, $T$ cells specific for ovalbumin did not stimulate the formation of new oligodendrocytes. In addition, infiltration of myelinspecific $T$ cells enhanced the sprouting response of calretinergic associational/commissural fibers within the dentate gyrus. These results have implications for the perception of MS pathogenesis because they show that infiltrating myelin-specific $T$ cells can stimulate oligodendrogenesis in the adult central nervous system. (Am J Pathol 2011, 179:2028-2041; DOI: 10.1016/j.ajpath.2011.06.006)

T cell infiltration, demyelination, and axonal damage are central pathologic features of multiple sclerosis (MS). Whereas the primary immune attack on oligodendrocytes and myelin is effected by T cells, ${ }^{1,2}$ remyelination occurs in acute plaques, also in the presence of $T$ cells. ${ }^{3,4}$ Remyelination depends on chondroitin sulfate NG2-expressing adult oligodendrocyte precursor cells (OPCs). ${ }^{5,6}$ OPCs retain the capacity to proliferate and differentiate into myelinating oligodendrocytes in response to toxic or inflammatory demyelination ${ }^{7-9}$ and other forms of central nervous system (CNS) injury such as ischemia, ${ }^{10}$ spinal cord injury, ${ }^{11,12}$ axonal lesions, ${ }^{13,14}$ and inflammation. ${ }^{15}$ During differentiation, OPCs downregulate NG2 as cells acquire markers of mature oligodendrocytes such as 2',3'-cyclic nucleotide 3'-phosphodiesterase (CNP). ${ }^{16}$

The axonal damage that occurs within and distal to the acute MS lesion can be modeled in the hippocampal dentate gyrus by transection of the perforant pathway (PP), resulting in degeneration of the PP axons and their myelin sheaths in the outer part of the molecular layer. ${ }^{17-19} \mathrm{PP}$ lesions also induce proliferation of OPCs, which results in formation of new oligodendrocytes. ${ }^{14}$ These newly formed oligodendrocytes are presumed to myelinate the axonal sprouts that extend from other afferent fiber systems in the dentate gyrus ${ }^{20,21}$ such as the associational/commissural afferents from the calretinergic hilar mossy cells. ${ }^{20,22,23}$ Indeed, in stratum radiatum of the hippocampal CA3 region, lesion-induced axonal sprouting is associated with formation of more oligodendrocytes and more myelin. ${ }^{24}$

Because remyelination ultimately fails in $\mathrm{MS}^{25}$ it is assumed that autoimmune demyelination reduces the capacity for myelin repair. ${ }^{26,27}$ We investigated the effect of myelin-specific $T$ cells on the formation of oligodendrocytes in the dentate gyrus of mice subjected to PP tran-

Supported by the Danish MS Society, the Michaelsen Foundation, the Graduate School of Immunology, the Danish Medical Association Research Foundation, the Lundbeckfoundation, the Leo Nielsen Foundation, Bent Bøgh and Wife's Foundation, the Foundation for Promotion of Medical Research, the Frimodt-Heineke Foundation, the King Christian $X$ Foundation, the Merchant Brogaard Foundation, the Senior Hospital Physician's Foundation, the Karen A Tholstrup Foundation, the Foundation for Neurological Research, the Frimodt Foundation, the Hede Nielsen Foundation, the Kurt Bønnelycke's Foundation, the Torben og Alice Nielsen Foundation, the Fru Lily Benthine Lund Foundation, the Jacob Madsen and Wife Olga Madsen Foundation, the Kathrine and Vigo Skovgaards Foundation, the Beckett-Foundation, the Warwara Larsen Foundation, and a grant from Alfred Helsted, MD.

Accepted for publication June 20, 2011.

Supplemental material for this article may be found on http://ajp. amjpathol.org or at doi: 10.1016/j.ajpath.2011.06.006.

Address reprint requests to Helle Hvilsted Nielsen, M.D., Ph.D., Neurobiology Research, Institute of Molecular Medicine, University of Southern Denmark, J.B. Winsløwsvej 25, 2nd floor, DK-5000 Odense C, Denmark. E-mail: hhnielsen@health.sdu.dk. 
section. Via adoptive transfer of T cells specific for myelin proteolipid protein (PLP) before axonal lesioning, infiltration of $T$ cells into the dentate gyrus was significantly enhanced, compared with limited T-cell infiltration in PPlesioned mice with adoptive transfer of ovalbumin (OVA)specific $T$ cells or lesioned naïve mice. A significantly higher increase in the number of postproliferative oligodendrocytes was observed in the PP-lesioned $\mathrm{T}_{\mathrm{PLP}}$-recipient mice than in PP-lesioned TOVA-recipient and naïve mice. Furthermore, the increased oligodendrogenesis was preceded by increased proliferation of $\mathrm{NG}^{+}$OPCs in the dentate gyrus. These changes correlated with an increased clearance of myelin debris and increased sprouting of calretinergic associational/commissural fibers. Our results demonstrate that myelin-specific T cells can stimulate oligodendrogenesis in vivo.

\section{Materials and Methods}

\section{Animals}

Female SJL mice aged 8 to 10 weeks were obtained from Taconic Europe A/S (Ejby, Denmark) and maintained in a pathogen-free temperature- and humidity-controlled environment with a 12-hour light-dark cycle, and were provided with food and water ad libitum. Experiments were approved by the National Danish Animal Care Committee (J.nr. 192000/561-272 and J.nr. 192000/51-272).

\section{Transfer of T Cells}

$T_{P L P}$ and $T_{\text {OVA }}$ were generated as previously described. ${ }^{28}$ Donor mice were immunized via two s.c. injections, at the base of the tail and in the flank, with $50 \mu \mathrm{L}$ emulsion of Mycobacterium tuberculosis H37 RA (2 mg/ $\mathrm{mL}$ ) (Difco Laboratories, Inc., Detroit, MI) in incomplete Freund's adjuvant solution (Difco Laboratories, Inc.) and $\mathrm{PLP}_{139-151}(1 \mathrm{mg} / \mathrm{mL})$ (KJ Ross-Petersen ApS, Klampenborg, Denmark) or ovalbumin (30 mg/mL) (Sigma-Aldrich Corp., St. Louis, MO). Lymph nodes were collected on day 11 , and cells were cultured for 4 days in RPMI-1640 medium (Invitrogen Corp., Carlsbad, CA) containing 10\% fetal bovine serum (Invitrogen Corp.), 2 mmol/L L-glutamine (Sigma-Aldrich Corp.), $50 \mu \mathrm{mol} / \mathrm{L}$ 2-mercaptoethanol (Bie \& Berntsen A/D, Herlev, Denmark), and $5 \mu \mathrm{g} / \mathrm{mL}$ PLP. Proliferation was measured using the Vybrant MTT Cell Proliferation Assay Kit (Invitrogen Corp.). $T_{\mathrm{PLP}}$ and $T_{\text {Ova }}$ cultures showed equal proliferation rates before cells were collected on a Ficoll-Hypaque gradient (Amersham Pharmacia Biotech, Inc., Piscataway, NJ), counted, and injected i.v. into recipient mice $\left(6 \times 10^{6}\right.$ blasts per mouse or $28 \%$ to $30 \%$ of the cells injected). $\mathrm{T}_{\mathrm{PLP}}$-and $\mathrm{T}_{\mathrm{OVA}}$-recipient mice ( $\mathrm{T}_{\mathrm{PLP}}$ and $\mathrm{T}_{\mathrm{OV} A}$ mice, respectively) were weighed and clinically evaluated daily. $T_{\text {OVA }}$ mice demonstrated no symptoms. $T_{P L P}$ mice reached experimental allergic encephalomyelitis (EAE) grade 0 to 2 before termination at 7 days post lesion (11 days post transfer). For studies of cytokine expression of T cells in vitro, $\mathrm{T}_{\mathrm{PLP}}$ and $\mathrm{T}_{\text {OVA }}$ cells were generated, cultivated, and harvested as described above, transferred into TRIzol (Invitrogen Corp.), and stored at $-80^{\circ} \mathrm{C}$. Lymph node cells from naïve mice served as controls.

\section{PP Transection}

Anterograde axonal degeneration was induced via stereotactic transection of the PP using a wire knife. ${ }^{14}$ Mice were PP lesioned at 4 days post transfer, when myelinspecific T cells usually enter the CNS after i.v. injection. ${ }^{29}$ Mice were euthanized at 2 days post lesion ( $11 \mathrm{~T}_{\mathrm{PLP}}, 8$ $\mathrm{T}_{\mathrm{OVA}}$, and 10 naïve) and 7 days post lesion ( $7 \mathrm{~T}_{\mathrm{PLP}}, 8$ $\mathrm{T}_{\mathrm{OVA}}$, and 6 naïve). Unlesioned T OVA and TPLP mice ( $n=$ 6 and 8, respectively) were euthanized at 11 days post transfer, when TPLP mice demonstrated symptoms of EAE grade 0 to 2. Unmanipulated mice $(n=6)$ and unlesioned the contralateral dentate gyrus served as controls. To study the cytokine profile using quantitative PCR (qPCR), a similar set of animals was generated $(n=8$ to 12 per group). For investigations of cellular proliferation and differentiation, animals received a i.p. bolus injection of $\mathrm{BrdU}$ (5'-bromo-2'-deoxyuridine) dissolved in isotonic saline solution $(50 \mathrm{mg} / \mathrm{kg})$ at 2 days post lesion. Animals euthanized at day 2 received the injection 1 hour before sacrifice.

\section{Fixation and Tissue Processing}

Mice were deeply anesthetized using $0.05 \mathrm{~mL}$ pentobarbital $(200 \mathrm{mg} / \mathrm{mL})$ and perfused through the left ventricle using $5 \mathrm{~mL} 0.15 \mathrm{mmol} / \mathrm{L}$ Sørensen phosphate buffer $(\mathrm{pH}$ 7.4) followed by $20 \mathrm{~mL} 4 \%$ paraformaldehyde in 0.15 $\mathrm{mmol} / \mathrm{L}$ Sørensen phosphate buffer ( $\mathrm{pH}$ 7.4). The brains were postfixed in $4 \%$ paraformaldehyde for $1 \frac{1}{2}$ hours, immersed in $20 \%$ sucrose overnight, frozen, and serially cut into $16-\mu \mathrm{m}$ parallel cryostat sections. For qPCR, animals were perfused using $20 \mathrm{~mL} 0.15 \mathrm{mmol} / \mathrm{L}$ Sørensen phosphate buffer, and the ipsilateral hippocampus was dissected and stored in TRIzol at $-80^{\circ} \mathrm{C}$. For in situ hybridization, PP-lesioned T TPP, T OVA and naïve mice ( $n=$ 3 or 4 per group) were decapitated, and the brains were frozen, cut as above, and stored at $-80^{\circ} \mathrm{C}$.

\section{Validation of PP Lesion}

The quality of the lesion was controlled using Fluoro-Jade staining. ${ }^{30}$ Only mice that demonstrated a dense band of green fluorescence in the outer molecular layer, reflecting complete transection of both the medial and lateral PP, were included in the study. ${ }^{30,31}$

\section{Diaminobenzidine Immunohistochemistry}

Neurofilament (NF) was detected by using primary monoclonal rat anti-mouse phosphorylated NF antibody (MAB5448; dilution 1:100; Chemicon International, Inc., Temecula, CA), secondary biotinylated species-specific monoclonal goat anti-rat antibody (RPN 1005; dilution 1:200; Amersham Pharmacia Biotech, Inc.), and streptavidin-horseradish peroxidase (P397; dilution 1:200; Dako A/S, Glostrup, Denmark), as described by Nielsen 
et al. ${ }^{14} \mathrm{~T}$ cells were visualized as described for NF using monoclonal rat anti-human CD3 antibody (MCA1477; diIution 1:200; AbD Serotec, Ltd., Kidlington, Oxfordshire, England). Cross-reactivity for murine CD3 was confirmed via location of $\mathrm{CD}^{+}$cells to the periarteriolar sheath in murine spleen sections. OPCs were visualized using polyclonal rabbit raised against chondroitin sulfate proteoglycan NG2 (AB5320; dilution 1:500; Chemicon International, Inc.). Oligodendrocytes and myelin were visualized using monoclonal mouse anti-rat Rip antibody (Developmental Studies Hybridoma Bank, University of lowa, lowa City, IA) recognizing 2', 3'-cyclic nucleotide $3^{\prime}$-phosphodiesterase. ${ }^{32,33}$ The antibody was biotinylated by Karsten Skjødt, University of Southern Denmark (Odense) and used at a concentration of 0.05 $\mathrm{mg} / \mathrm{mL}$. NG2 and CNP stainings were counterstained using toluidine blue to facilitate cell counting. Calretinergic fibers were visualized using polyclonal rabbit anticalretinin antibody $(7699 / 3 \mathrm{H}$; dilution 1:10.000; Swant, Inc., Marly, Switzerland) diluted in $10 \%$ fetal bovine serum containing $1 \%$ triton. Rinses were extended to $3 \times 2$ hours. Primary and secondary antibodies were incubated overnight at $4^{\circ} \mathrm{C}$.

\section{Diaminobenzidine/Alkaline Phosphatase Double Immunohistochemistry}

After staining for NG2 or CNP, sections were rinsed in $2 x$ standard saline citrate solution $[300 \mathrm{mmol} / \mathrm{L} \mathrm{NaCl}$ and 30 $\mathrm{mmol} / \mathrm{L}$ and sodium citrate $(\mathrm{pH} \mathrm{8.0)}$ ] for $2 \times 15$ minutes at room temperature, incubated in a $49 \%$ solution of formamide in $2 \times$ standard saline citrate solution for 2 hours at $60^{\circ} \mathrm{C}$, rinsed in $2 \times$ standard saline citrate solution for $2 \times$ 5 minutes at $60^{\circ} \mathrm{C}$, and incubated in $2 \mathrm{~N} \mathrm{HCl}$ in 0.05 $\mathrm{mmol} / \mathrm{L}$ Tris-buffered saline solution for 30 minutes at $37^{\circ} \mathrm{C}$. Sections were rinsed and incubated using monoclonal rat anti-BrdU antibody (AB6326; dilution 1:100; Abcam Ltd., Cambridge, England), which was detected using biotinylated goat anti-rat Ig antibody (RPN 1005; dilution 1:200; Amersham Pharmacia Biotech, Inc.), and alkaline phosphatase-conjugated streptavidin (P396; Dako $A / S$ ), and incubated in an alkaline phosphatase developer as previously described. ${ }^{34}$

\section{Double Immunofluorescence Histochemistry}

Calretinergic fibers were detected using Alexa 488-conjugated sodium arsenite (S-32354; dilution 1:500; Invitrogen Corp.) along with fluorescence detection of myelin basic protein (MBP) using Alexa 594-conjugated goat anti-rabbit Ig (A-11012; dilution 1:500; Invitrogen Corp.) as described by Nielsen et al. ${ }^{35}$ The cellular nuclei were visualized using the nucleic acid stain DAPI (D3571; Invitrogen Corp.), which was added in a concentration of $300 \mathrm{nmol} / \mathrm{L}$ to the Tris-buffered saline solution during the last rinse.

Non-specific staining was controlled for by incubation without the primary antibody, with an isotype-specific control (rat IgG1 or rat IgG2b; Nordic Biosite AB, Täby,
Sweden) or with rabbit (X902) or goat (X907) serum (both from Dako $A / S$ ), and exhibited no staining.

\section{In Situ Hybridization}

A mixture of two alkaline phosphatase-labeled DNA probes (DNA Technology A/S, Risskov, Denmark) complementary to bases 169 to 196 (5'-GGCTTTCAATGACTGTGCCGTGGCAGTA-3') and 530 to 557 (5'-CGCTTCCTGAGGCTGGATTCCGGCAACA-3') was used for detection of interferon- $\gamma(\mathrm{IFN}-\gamma)$ CDNA. Probe specificity was confirmed by hybridizing with each probe alone or with a probe mixture, showing identical regional and cellular localization of the in situ signal but with a stronger signal in sections hybridized with the probe mixture. In addition, sections pretreated with RNase A (27-0323-01; Amersham Pharmacia Biotech, Inc.) before hybridization or hybridized using a 100-fold excess of unlabeled IFN- $\gamma$ probe mixture or buffer alone were devoid of signal (see Supplemental Figure S1B at http://ajp.amjpathol.org).

\section{qPCR}

RNA extraction, cDNA synthesis, and gPCR were performed on dissected hippocampi ${ }^{36}$ using a sequence detection system (PRISM 7300; Applied Biosystems, Inc., Foster City, CA) and using either a Taqman probe (TAG Copenhagen A/S, Copenhagen, Denmark) or SYBR Green (Cambrex Bio Science Walkersville, Inc., Walkersville, MD) as fluorescent reporter molecules. A standard curve was prepared from a fivefold dilution series of cDNA from spinal cord obtained from animals with symptoms of EAE. Primers and probes for tumor necrosis factor (TNF)- $\alpha$ and IFN- $\gamma$ and the $\varepsilon$-chain of the CD3 complex were used as previously described. ${ }^{34,37}$ For IL-4, we used forward primer $5^{\prime}$ AAACATGGGAAAACTCCA-3' and reverse primer 5'CAGCTTATCGATGAATCCA-3'); for IL-10, forward primer 5'-AGGACTTTAAGGGTTACT-3' and reverse primer 5'-AATGCTCCTTGATTTCTG-3'; for IL-17, forward primer 5'GCTTCATCTGTGTCTCTG-3' and reverse primer 5'GAACGGTTGAGGTAGTCT-3'). For NG2, we used forward primer 5'-TCCCGGAGAGAGGTGGAAGAG-3' and reverse primer 5'-GGTCCATCTCTGAGGCATTAGC, and probe 5'-AAGGCGTCTGTCTGTGTCTCACTTCCATCA-3'. For insulin-like growth factor-1 (IGF-1), we used forward primer 5'-CCGAGGGGC TTTTACTTCAACAA-3' and reverse primer 5'-CGGAAGCAACACTCATCCACAA-3'. For brain-derived neurotrophic factor (BDNF), we used forward primer 5'-GGCCCAACGAAGAAAACCAT-3' and reverse primer 5'-AGCATCACCCGGGAAGTGT-3'. Specificity of the PCR primer/probe set was validated as described in Meldgaard et al. ${ }^{36}$ Test gene data were normalized to the reference gene hypoxanthine phosphoribosyltransferase 1 and calibrated to a pool of control samples from animals not operated on. mRNA expression was normalized to the expression of unmanipulated controls, which was set to 1.0. IFN- $\gamma$, IL-4, $\mathrm{IL}-17$, and BDNF mRNA expressions were normalized to the expression in unlesioned TOVA mice because we were unable to detect IFN- $\gamma$, IL-4, IL-17, or BDNF mRNA from these cytokines in the hippocampus of unlesioned 
naïve mice. In cases in which mRNA was undetectable (more than 40 cycles or undetermined), the fold increase was set at zero. Changes in mRNA level less than twofold were not subjected to statistical analysis. ${ }^{36}$

\section{Cell Counting}

Cell counting in the molecular layer of the temporal dentate gyrus of PP-lesioned mice was performed using the computer-assisted cast-grid microscope system (CAST2; Visiopharm A/S, Hoersholm, Denmark). The $\mathrm{CD}^{+}$cells were defined by their brown plasmalemma. $\mathrm{NG}_{2}{ }^{+}$cells were defined by a toluidine blue-stained nucleus surrounded by a brown plasmalemma from which more than one process extended. $\mathrm{CNP}^{+}$cells were defined by a toluidine blue-stained nucleus surrounded by a brown plasmalemma. $\mathrm{BrdU}^{+} \mathrm{NG}^{+}$cells and $\mathrm{BrdU}^{+} \mathrm{CNP}^{+}$cells were defined as $\mathrm{NG}^{+}$and $\mathrm{CNP}^{+}$cells with a bluish black nucleus. To count the cells using the method of Nielsen et al., ${ }^{14}$ cells were counted in the molecular layer of the dentate gyrus in 10 parallel sections $160 \mu \mathrm{m}$ apart using a counting frame of $4900 \mu \mathrm{m}^{2}$ (fraction of total area, 61\%) along the rostrocaudal axis of the hippocampus, starting in the section in which the dentate gyrus first demonstrated a typical $U$ shape (-1900 $\mu \mathrm{m}$ from the bregma), as previously reported. ${ }^{14}$ At least 150 to 200 single-labeled $\mathrm{NG}^{+}$or $\mathrm{CNP}^{+}$cells were counted per animal. To account for potential differences in the quality of the stainings, cell numbers are reported as the ratio between cell numbers obtained from the deafferented ipsilateral molecular layer compared with cell numbers obtained from the contralateral molecular layer $\left(\mathrm{NG}_{\mathrm{i} / \mathrm{c}}\right.$ and $\left.\mathrm{CNP}_{\mathrm{i} / \mathrm{c}}\right)$. Because of the virtual absence of $\mathrm{T}$ cells in the contralateral molecular layer, the total number of counted $\mathrm{CD}^{+} \mathrm{T}$ cells is given.

\section{Area Estimations}

To estimate the area of the inner and outer molecular layers, calretinin-stained sections were analyzed using the CAST2 system. The number of points hitting the inner and outer molecular layers $(P)$ was counted on sections with a mean distance $(t)$ of $160 \mu \mathrm{m}$. The sum of the areas of various brain sections was calculated by multiplying the total number of counted points $(P)$ with the computergiven factor of area per point $\left(A_{\text {point }}=6.8582 \mathrm{~mm}^{2}\right)$. The total area $\left(A_{\text {total }}\right)$ was calculated using the formula $A_{\text {total }}=$ $\Sigma \mathrm{P} \times A_{\text {point }} \times t$. Results are given as the ratio between the area of the inner molecular layer and the entire molecular layer.

\section{Statistical Analysis}

Results are given as mean \pm SD. Comparison of medians in two groups was performed using the MannWhitney rank sum test. For multiple comparisons, Kruskal-Wallis one-way analysis of variance was performed, followed by Dunn's multiple comparisons test. Statistical analyses were performed using Prism 4.0b software for Macintosh (GraphPad Software, Inc., San
Diego, CA). $P$ values are indicated as follows: ${ }^{\star} P<0.05$, ${ }^{\star \star} P<0.01$, and ${ }^{\star \star \star} P<0.001$.

\section{Results}

\section{Afferent Fibers with Potential for Sprouting Persist after PP Lesioning}

Staining for NF directly visualized the PP fibers terminating as a broad band of $\mathrm{NF}^{+}$fibers in the outer molecular layer (Figure 1, A and C). As expected, this band of $\mathrm{NF}^{+}$ fibers was completely obliterated by transection of the $\mathrm{PP}$, which focused attention on the $\mathrm{NF}^{+}$fiber systems that persisted in the inner and outer molecular layers of the
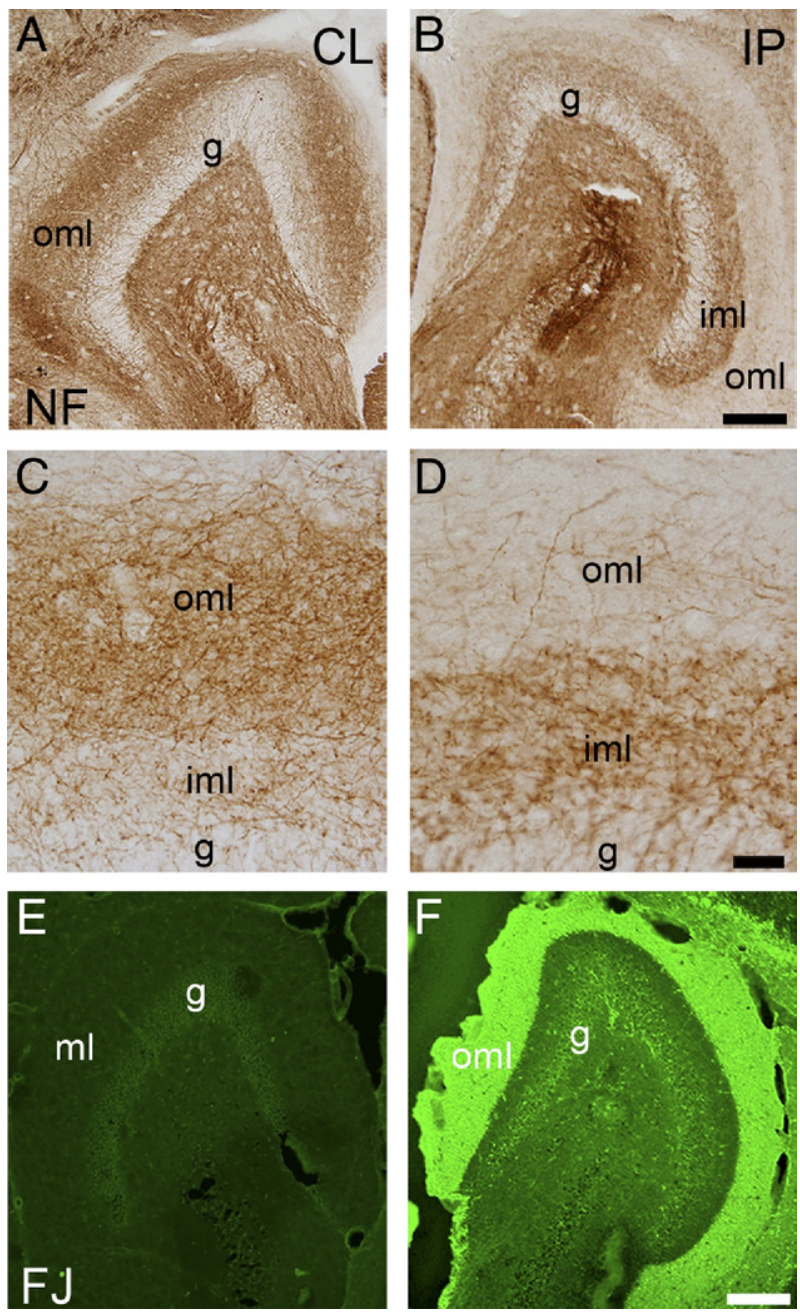

Figure 1. Afferent fibers with potential for sprouting persist after PP lesioning. A-D: Staining for NF at 7 days post lesion demonstrates the $\mathrm{NF}^{+}$fibers in intact contralateral dentate gyrus $(\mathbf{A}$ and $\mathbf{C})$ and the reduced amount of $\mathrm{NF}^{+}$fibers in the outer molecular layer (oml) of the deafferented ipsilateral (IP) dentate gyrus (B and D). The $\mathrm{NF}^{+}$fibers that persist in the outer molecular layer may represent calretinergic and cholinergic afferent fibers and other afferent fibers not part of the PP. E and F: Fluoro-Jade staining of the dentate gyrus at 7 days post lesion. The anterograde axonal and terminal degeneration is visualized as an intense band of green fluorescence in the deafferented outer molecular layer in the ipsilateral dentate gyrus (E). No degeneration is observed in the contralateral dentate gyrus (F). CL, contralateral layer; g, granule cell layer; iml, inner molecular layer; ml, molecular layer. Scale bars: $20 \mu \mathrm{m}(\mathbf{C}$ and $\mathbf{D}) ; 150 \mu \mathrm{m}(\mathbf{A}, \mathbf{B}, \mathbf{E}$, and $\mathbf{F})$ 
dentate gyrus after PP lesioning (Figure 1, B and D). Furthermore, sections from all PP-lesioned $T_{P L P}, T_{\text {OVA }}$, and naïve mice were stained with Fluoro-Jade for visualization of the area of degenerating axons and terminals. As expected, Fluoro-Jade staining demonstrated a sharply demarcated band of green fluorescence in the outer part of the molecular layer of the ipsilateral dentate gyrus, at both 2 and 7 days post lesion, in contrast to the non-deafferented contralateral molecular layer, which demonstrated no staining (Figure 1, E and F).

\section{Myelin-Specific T Cells Infiltrate Zones of Axonal Degeneration}

To verify that myelin-specific T cells infiltrated the outer molecular layer at the time of maximal OPC proliferation and remained during the period of OPC differentiation, ${ }^{14}$ we studied T-cell infiltration in $T_{P L P}, T_{O V A}$, and naïve mice at 2 and 7 days post lesion (Figure 2A). Compared with few infiltrating $\mathrm{CD}^{+}{ }^{+} \mathrm{T}$ cells in PP-lesioned TOVA and naïve mice, there was a significantly higher infiltration of $\mathrm{CD}^{+} \mathrm{T}$ cells in the dentate gyrus and surrounding meninges in $T_{P L P}$ mice at both 2 and 7 days post lesion (Figure 2, A and B; see also Supplemental Table S1 at http://ajp.amipathol.org). In line with these observations, hippocampi from $T_{\text {PLP }}$ mice also demonstrated a significantly higher increase in $\mathrm{CD} 3 \varepsilon$ mRNA expression than did hippocampi from Tova and naïve mice at both 2 and 7 days post lesion (Figure 2B; see also Supplemental Table S1 at http://ajp.amjpathol.org). The number of T cells and CD3 $\varepsilon$ mRNA expression in PP-lesioned naïve mice and unlesioned $T_{\mathrm{PLP}}$ and $\mathrm{T}_{\mathrm{OVA}}$ mice were close to the baseline in unlesioned naïve mice (see Supplemental Table S1 at $h$ ttp://ajp.amjpathol.org).

\section{Cytokine Expression of Infiltrating T Cells}

To determine the activation state of the infiltrating $T$ cells, we investigated the cytokine expression in hippocampi of PP-lesioned TPLP, TOVA , and naïve mice at both 2 and 7
A

$\mathrm{dpl}$

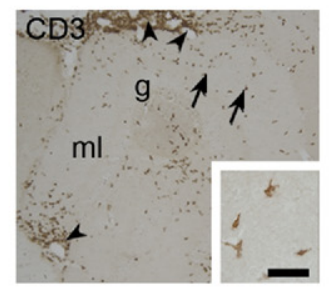

$7 \mathrm{dpl}$

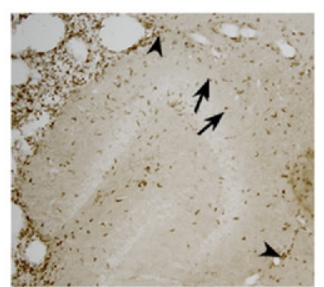

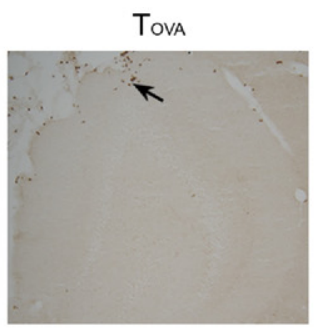

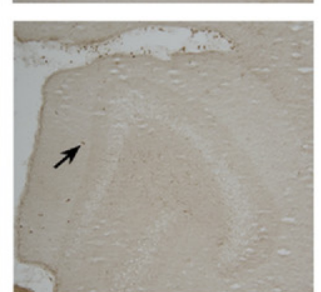

C
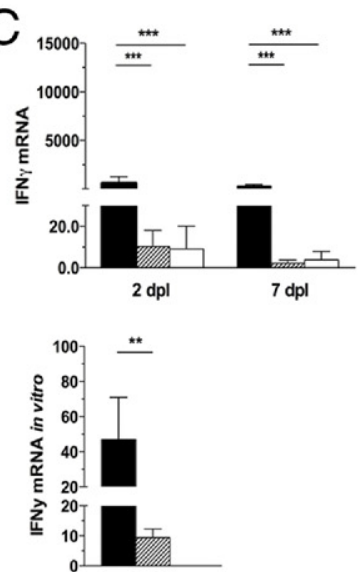
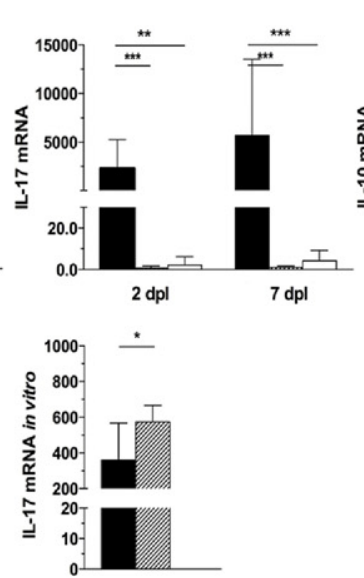

Naïve
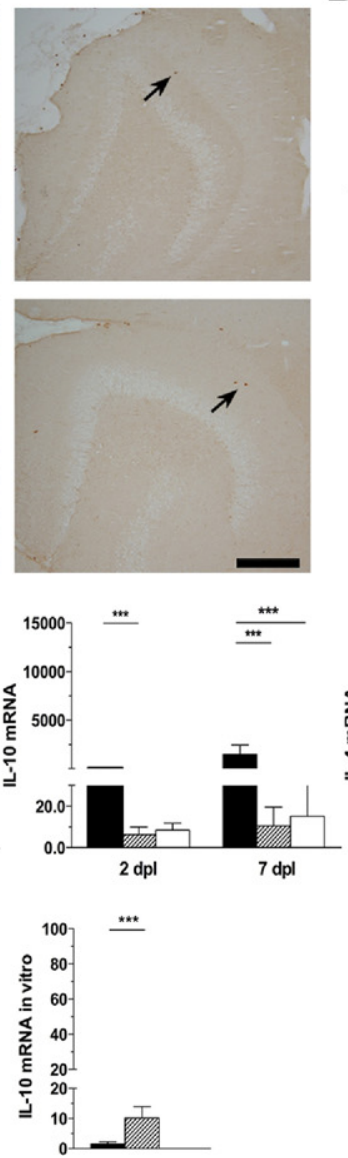

B
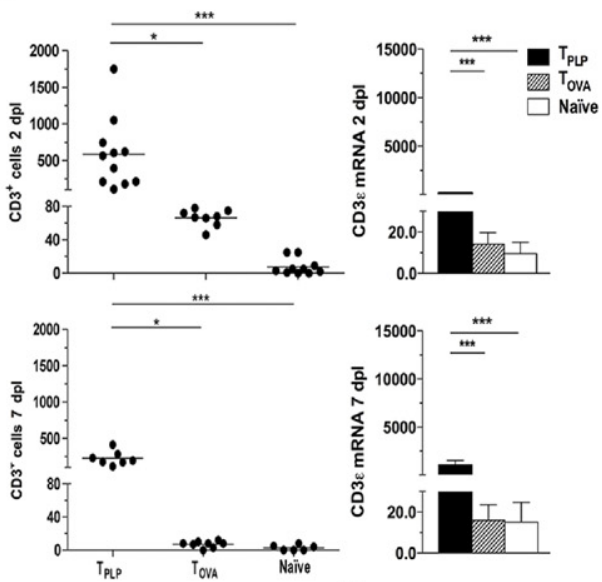

$\mathrm{D}$
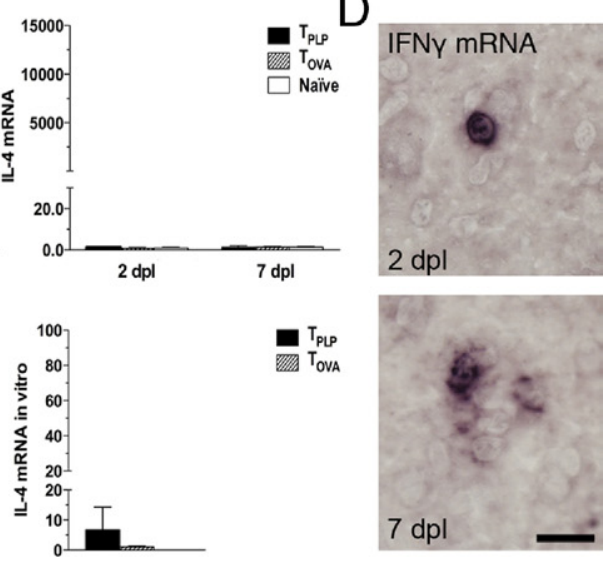

Figure 2. $\mathrm{T}$ cells infiltrate zones of axonal degeneration in lesioned $\mathrm{T}_{\mathrm{P}}$ mice. A: Increased infiltration of $\mathrm{CD} 3^{+} \mathrm{T}$ cells $($ arrows) in the molecular layer ( $\mathrm{ml}$ ) of PP-lesioned $\mathrm{T}_{\text {PLP }}$ animals compared with scarce $\mathrm{T}$ cells in $\mathrm{T}_{\mathrm{OVA}}$ and naïve mice at 2 and 7 days post lesion. Note the meningeal infiltration, which is most pronounced in lesioned $\mathrm{T}_{\mathrm{PLP}}$ animals (arrowheads). g, granule cell layer. Scale bars: $10 \mu \mathrm{m} ; 250 \mu \mathrm{m}$ (inset). B: Cell counting data demonstrate an enhanced number of $\mathrm{CD}^{+}{ }^{+} \mathrm{T}$ cells in the molecular layer, and qPCR demonstrated enhanced expression of CD $3 \varepsilon$ mRNA in hippocampi of $\mathrm{T}_{\mathrm{PLP}}$ mice compared with $\mathrm{T}_{\mathrm{OV}}$ and naïve mice at 2 and 7 days post lesion. Lines represent the mean. ${ }^{*} P<0.05 ;{ }^{* * * *} P<0.001$. C: qPCR detection demonstrates enhanced mRNA expression of IFN- $\gamma$, IL-17, and IL-10 but not IL-4 in hippocampi of $\mathrm{T}_{\mathrm{PLP}}$ mice compared with $\mathrm{T}_{\mathrm{OVA}}$ and naïve mice at 2 and 7 days post lesion (top row) and in $\mathrm{T}_{\mathrm{PLP}}$ mice compared with $\mathrm{T}_{\mathrm{OVA}}$ mice in vitro (bottom row). $\mathrm{T}_{\mathrm{OVA}}$ mice exhibited only a modest increase in IFN- $\gamma$ in vivo and in vitro. Results are given as mean $\pm \mathrm{SD}$. ${ }^{*} P<0.05 ;{ }^{* *} P<0.01 ;{ }^{* * *} P<0.001$. D: $I n$ situ hybridization demonstrates scarce IFN- $\gamma$ mRNA-expressing cells in the hippocampus proper at 2 and 7 days post lesion. Scale bar $=20 \mu \mathrm{m}$. 
days post lesion. The $T_{\text {PLP }}$ mice demonstrated a several hundred-fold to several thousand-fold increase in IFN- $\gamma$, $\mathrm{IL}-17$, and IL-10 mRNA expression at both observation times, compared with a few-fold increase in PP-lesioned $\mathrm{T}_{\mathrm{OVA}}$ and naïve mice (Figure $2 \mathrm{C}$; see also Supplemental Table S1 at http://ajp.amjpathol.org). In contrast, IL-4 mRNA demonstrated no significant changes in mRNA expression in any of the groups (Figure 2C; see also Supplemental Table S1 at $h$ ttp://ajp.amjpathol.org).

Although the fold increase in IFN- $\gamma$ mRNA in the hippocampi of $T_{P L P}$ mice was huge, in situ detection clearly demonstrated that IFN- $\gamma$ mRNA was confined to single cells located in the hippocampus (Figure 2D; see also Supplemental Figure S1A at http://ajp.amjpathol.org), while being more abundant in the meninges and in the scattered perivascular infiltrates present in the brain stem and cerebellum (see Figure S1B at http://ajp.amjpathol. org). IFN- $\gamma$ mRNA expressing cells were not detected in PP-lesioned T OVA and naïve mice (see Supplemental Figure S1A at $h$ ttp://ajp.amjpathol.org), which was in line with the variable detection of IFN- $\gamma$ mRNA in these mice (see Supplemental Table S1 at $h$ ttp://ajp.amjpathol.org).

To investigate whether the increase in IFN- $\gamma, \mathrm{IL}-17$, and IL-10 mRNA expression was the result of CNS-T cell interaction, cytokine mRNA expression was also quantified in $T_{P L P}$ and $T_{O V A}$ mice and in lymph node cells from naîve mice, the latter being included for control (see Supplemental Table S1 at http://ajp.amjpathol.org). TPLP mice were characterized by a particularly high expression of IFN $\gamma$, but also expressed high concentrations of IL-17 mRNA and some IL-4 mRNA (Figure 2C). TovA mice also expressed high concentrations of IL-17 mRNA and some IFN- $\gamma$ and IL-10 mRNA, consistent with the findings of others. ${ }^{28}$

Considered together, the cytokine profile and pattern of infiltration with $\mathrm{CD}^{+}{ }^{+} \mathrm{T}$ cells in PP-lesioned $\mathrm{T}_{\mathrm{PLP}}$ mice suggested the presence of subpopulations of $T$ cells consistent with a Th1 response, but also Th17 and, possibly regulatory $T$ cells response, similar to that of $E A E$ lesions, ${ }^{38}$ although here associated with enhanced oligodendrogenesis rather than inflammatory demyelination.

\section{Myelin-Reactive T Cells Affect the OPC Response to Axonal Lesions}

To study the effect of activated myelin-specific T cells on the axonal lesion-induced response of the $\mathrm{NG}^{+}$OPC population, we compared the morphologic and numeric OPC response in PP-lesioned $\mathrm{T}_{\mathrm{PLP}}, \mathrm{T}_{\mathrm{OVA}}$, and naïve mice, initially focusing on mice surviving 2 days post lesion. Characteristic of the OPC response in the PPlesioned $\mathrm{T}_{\mathrm{PLP}}$ mice, the $\mathrm{NG}_{2}{ }^{+}$cells located at the transition between the inner and outer molecular layers had redirected their processes so that they radiated deep into the T cell-infiltrated outer molecular layer at 2 days post lesion (Figure 3A). This response was distinctly different from the OPC response in the PP-lesioned T OVA and naîve mice, in which the OPCs had transformed into hypertrophic and hyper-ramified cells, with their processes radiating in all directions (Figure $3 \mathrm{~A}$ ).
Because we had shown previously that $\mathrm{NG}^{+}$cells in the contralateral hippocampus are unaffected by the lesion, ${ }^{14}$ we calculated the lesion-induced increase in the number of OPCs as a ratio, $N G 2_{i / c}$, of the cell numbers in the ipsilateral and contralateral molecular layers. Quantification demonstrated a comparable increase in the $N G 2_{i / c}$ ratio of 1.25 and 1.30 in $\mathrm{T}_{\mathrm{OVA}}$ and naïve mice, respectively, at 2 days post lesion (Figure 3C; see also Supplemental Table S1 at http://ajp.amjpathol.org). This represented $25 \%$ and $30 \%$ increases in OPC numbers in the PP-lesioned $\mathrm{T}_{\mathrm{OV} \text { A }}$ and naïve mice, identical to previous findings in PP-lesioned naïve mice. ${ }^{14}$ In contrast, the $\mathrm{T}_{\mathrm{PLP}}$ mice, demonstrating an $\mathrm{NG} 2_{\mathrm{i} / \mathrm{c}}$ ratio of 1.04 at 2 days post lesion, completely failed to demonstrate a lesioninduced increase in OPC numbers (Figure 3C; see also Supplemental Table S1 at $h$ ttp://ajp.amjpathol.org). This was additionally supported by comparison of the lesioninduced increase in NG2 mRNA levels in the various groups of mice, which showed a trend toward unchanged NG2 mRNA expression at 2 days post lesion in $\mathrm{T}_{\mathrm{PLP}}$ mice compared with the 1.2-fold increase in PPlesioned naîve mice (Figure 3D; see also Supplemental Table S1 at $h$ ttp://ajp.amjpathol.org).

At 7 days post lesion, both the $N G 2_{i / c}$ ratio and $N G 2$ mRNA expression in PP-lesioned $\mathrm{T}_{\mathrm{PLP}}$ mice were comparable to the values obtained in PP-lesioned $\mathrm{T}_{\text {OvA }}$ and naïve mice (Figure 3, C and D; see also Supplemental Table S1 at $h$ ttp://ajp.amjpathol.org). Furthermore, as previously reported in PP-lesioned naîve mice, ${ }^{14}$ the OPCs were less distinctly stained in all groups of mice (Figure $3 \mathrm{~A}$ ), possibly because of protease-mediated cleavage of the ectodomain of NG2 chondroitin sulfate. ${ }^{39}$

\section{Lesion-Induced OPC Proliferation Is Stimulated by Myelin-Reactive T Cells}

The abrogation of the axonal lesion-induced increase in the $\mathrm{NG}^{+}$OPC population in the $\mathrm{T}_{\mathrm{PLP}}$ mice at 2 days post lesion might be explained by either reduced proliferation or increased proliferation and accelerated differentiation of OPCs. Therefore, we investigated OPC proliferation by giving mice a bolus injection of the thymidine analog BrdU at 1 hour before termination at 2 days post lesion. The $T_{P L P}$ mice demonstrated a significantly higher (10fold) increase in $\mathrm{BrdU}^{+} \mathrm{NG}_{2}{ }^{+}$OPCs, compared with an approximately fourfold increase in $\mathrm{T}_{\mathrm{OVA}}$ and naïve mice (Figure 3B; see also Supplemental Table S1 at http:// ajp.amjpathol.org). Furthermore, many of the activated $\mathrm{NG}_{2}{ }^{+}$OPCs extending their processes into the $\mathrm{T}$ cellinfiltrated outer molecular layer had incorporated BrdU (Figure 3B), which demonstrated that they had recently proliferated. The OPC responses in PP-lesioned TOVA and naïve mice were comparable, with scattered hypertrophic and highly branched cells co-labeled for BrdU and NG2 (data not shown). Numerous single-labeled $\mathrm{BrdU}^{+}$cells were also observed, mainly corresponding to the nuclei of mitotic microglia. ${ }^{30} \mathrm{~A}$ few $\mathrm{BrdU}^{+} \mathrm{NG}^{+}$ OPCs were also observed in the contralateral hippocampus of PP-lesioned $T_{P L P}, T_{O V A}$, and naïve mice, reflecting baseline proliferation. ${ }^{5,14,40}$ These observations showed 
A

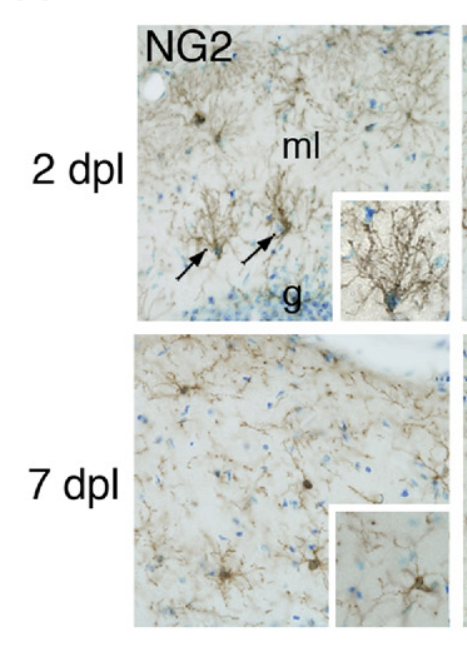

Tova
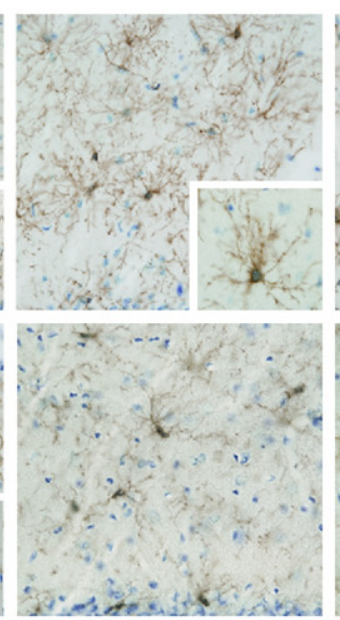

Naïve

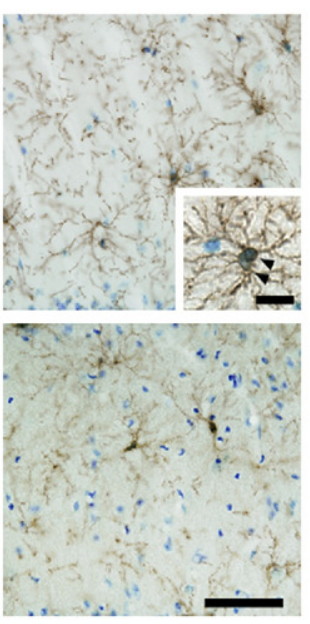

C

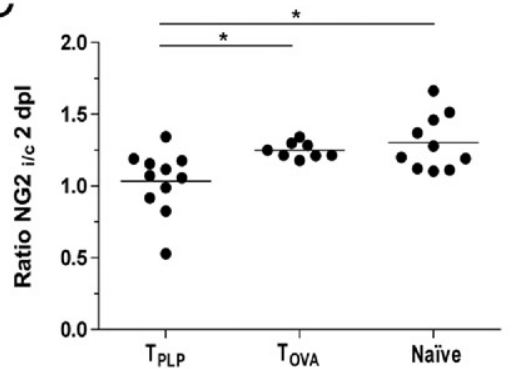

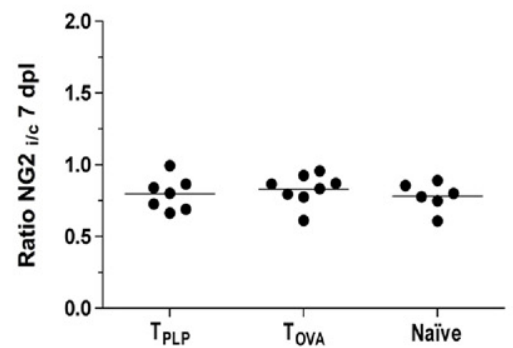

B

TPLP

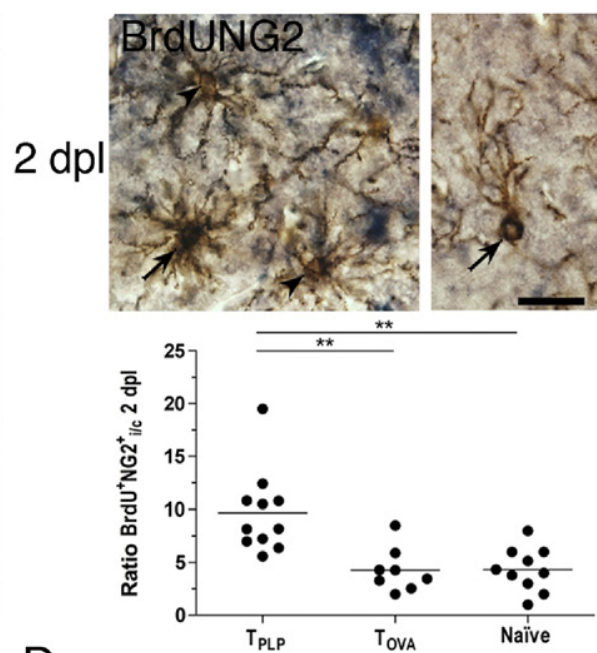

D

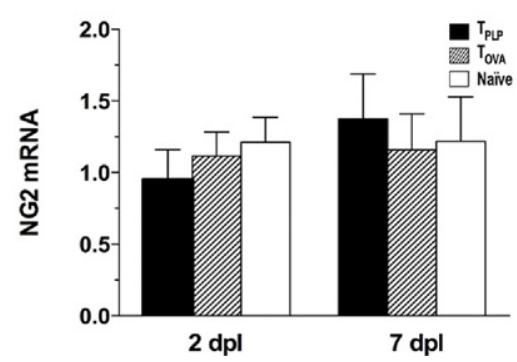

Figure 3. Myelin-reactive T cells stimulate OPC proliferation and differentiation in response to lesioning. A: NG2 staining demonstrates activated NG2 ${ }^{+}$OPC at 2 days post lesion. Hypertrophic cells (inset in $\mathrm{T}_{\mathrm{OVA}}$ ) and cellular double profiles (inset in Naïve) are observed in all groups of PP-lesioned mice. In $\mathrm{T}_{\mathrm{PLP}}$ mice, $\mathrm{NG}^{+}$cells additionally extended their processes into the area of $\mathrm{T}$ cell infiltration (arrows and inset). At 7 days post lesion, the NG2 ${ }^{+}$cells exhibited a similar structure in all groups, but were difficult to distinguish. Sections were counterstained with toluidine blue for visualization of cellular nuclei. $g$, granule cell layer; $m l$, molecular layer. Scale bars: $25 \mu \mathrm{m} ; 10 \mu \mathrm{m}$ (inset). B: BrdU incorporation into mitotic NG2 ${ }^{+}$cell (left arrow) together with nonmitotic NG2 ${ }^{+}$cells (left arrowheads) at 2 days post lesion. BrdU incorporation was also observed in $\mathrm{NG}^{+}$cells extending their processes into the outer molecular layer (right arrow). Scale bar $=10 \mu \mathrm{m}$. Ipsilateral and contralateral ratios of $\mathrm{BrdU}^{+} \mathrm{NG}^{+}$cells at 2 days post lesion demonstrate a significantly elevated proliferation in $\mathrm{T}_{\mathrm{PLP}}$ mice compared with $\mathrm{T}_{\mathrm{OVA}}$ and naïve mice. Lines mark the mean. ${ }^{* * *} P<0.01$. C: $\mathrm{NG}^{+}$cells given as ipsilateral and contralateral ratios in the molecular layer in $\mathrm{T}_{\mathrm{PLP}}$ mice at 2 days post lesion failed to show lesion-induced proliferation. At 7 days post lesion, there was no longer any difference between the groups. D: qPCR

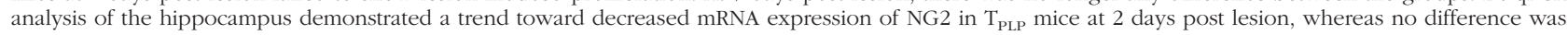
observed at 7 days post lesion. Results are given as mean \pm SD.

that myelin-specific $T$ cells significantly stimulated the proliferation of $\mathrm{NG}_{2}^{+}$OPCs. This suggested that the abrogation of the lesion-induced increase in the $\mathrm{NG}^{+}$cell population in $T_{\text {PLP }}$ mice at 2 days post lesion was due to accelerated differentiation of recently proliferated OPCs.

\section{Increased OPC Proliferation Translates into Increased Numbers of Oligodendrocytes}

To clarify whether the increased proliferation of OPCs at 2 days post lesion translated into an increased number of newly generated oligodendrocytes at 7 days post lesion, we quantified the number of $\mathrm{CNP}^{+}$cells and the number of $\mathrm{BrdU}^{+} \mathrm{CNP}^{+}$cells in $\mathrm{T}_{\mathrm{PLP}}, \mathrm{T}_{\mathrm{OVA}}$, and naïve mice at 7 days post lesion. Results are given as a ratio of $\mathrm{CNP}^{+}$or $\mathrm{BrdU}^{+} \mathrm{CNP}^{+}$cells in the ipsilateral and contralateral molecular layers. Although examination of CNP-stained sections obtained from $T_{P L P}, T_{O V A}$, and naïve mice revealed no differences in cellular structure (Figure 4A), PP lesions in $T_{P L P}$ mice resulted in a $C_{\text {N }}$ i/c ratio of 1.25 , which was significantly increased compared with an unchanged $\mathrm{CNP}_{\mathrm{i} / \mathrm{c}}$ ratio in PP-lesioned Tova and naïve mice (Figure
4B; see also Supplemental Table S1 at http://ajp. amjpathol.org). This corresponded to a $25 \%$ increase in $\mathrm{CNP}^{+}$oligodendrocytes in the $\mathrm{T}_{\mathrm{PLP}}$ mice, compared with unchanged numbers in Tova and naïve mice. Furthermore, compared with $T_{\text {OVA }}$ and naïve mice, the $T_{P L P}$ mice demonstrated a significantly higher $\mathrm{BrdU}^{+} \mathrm{CNP}^{+}{ }_{\mathrm{i} / \mathrm{c}}$ ratio (Figure 4, C and D). Thus, $28 \%$ of the $\mathrm{CNP}^{+}$cells had incorporated $\mathrm{BrdU}$ in $\mathrm{T}_{\mathrm{PLP}}$ mice, compared with $12 \%$ in Tova mice and $14 \%$ in naïve mice. Observations of $\mathrm{BrdU}^{+} \mathrm{CNP}^{+}$cells extending their processes toward myelinated fibers in $T_{\text {PLP }}$ mice (Figure $4 \mathrm{C}$ ) but not in $\mathrm{T}_{\text {OVA }}$ and naïve mice (data not shown) suggested that the recently proliferated oligodendrocytes were engaged in myelination and that this phenomenon was most frequent in PP-lesioned mice that had received myelin-specific $\mathrm{T}$ cells.

\section{Myelin-Reactive T Cells Enhance Clearance of Myelin Debris}

Because we had previously demonstrated that PP lesions result in accumulation of myelin debris in the outer mo- 


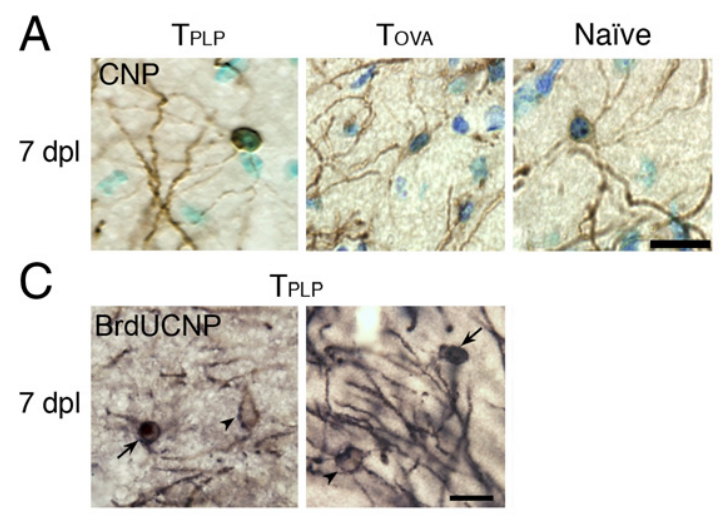

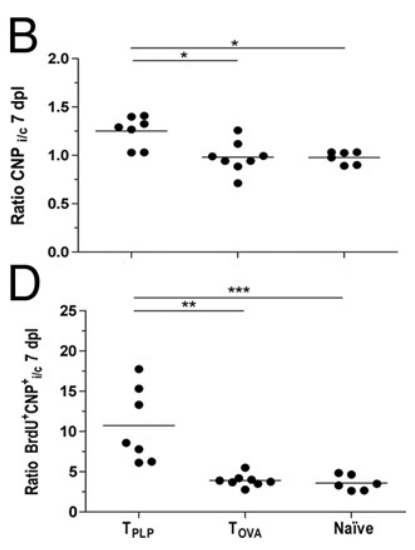

\begin{abstract}
Figure 4. Enhanced oligodendrogenesis in $\mathrm{T}_{\mathrm{PLP}}$ mice at 7 days post lesion. A: CNP-stained sections demonstrated no differences in oligodendrocyte structure (inset) in $\mathrm{T}_{\mathrm{PLP}}, \mathrm{T}_{\mathrm{OVA}}$, and naive mice at 7 days post lesion, but increased clearance of myelin debris in $\mathrm{T}_{\text {PLP }}$ mice. Sections were counterstained using toluidine blue. Scale bar $=10 \mu \mathrm{m}$. B: Ipsilateral and contralateral ratios of $\mathrm{CNP}^{+}$cells in the outer molecular layer at 7 days post lesion demonstrate an increased ratio in $\mathrm{T}_{\mathrm{PLP}}$ mice. Lines mark the mean ${ }^{*} P<0.05$. C: Postproliferative $\mathrm{BrdU}^{+} \mathrm{CNP}^{+}$oligodendrocyte (left arrow) in $\mathrm{T}_{\text {PLP }}$ mouse at 7 days post lesion, together with a non-dividing $\mathrm{CNP}^{+}$oligodendrocyte (left arrowhead). $\mathrm{BrdU}^{+} \mathrm{CNP}^{+}$cells with processes extending toward myelinated fibers (right arrow) together with single-labeled cells (righ arrowhead). Scale bar $=10 \mu \mathrm{m}$. D: Ipsilateral and contralateral ratios of $\mathrm{BrdU}^{+} \mathrm{CNP}^{+}$cells at 7 days post lesion demonstrate increased ratios in $\mathrm{T}_{\mathrm{PLP}}$ mice compared with $\mathrm{T}_{\mathrm{OVA}}$ and naïve mice. Lines mark the mean. ${ }^{\text {*ak }} P<0.01 ;{ }^{* * a p k} P<0.001$
\end{abstract}

lecular layer at 7 days post lesion ${ }^{41}$ and that microglial clearance of myelin debris is stimulated by infiltrating $\mathrm{T}_{\mathrm{MBP}}{ }^{35}$ we also investigated the clearance of $\mathrm{CNP}^{+}$myelin debris in PP-lesioned $T_{P L P}, T_{\text {OVA }}$, and naïve mice (see Supplemental Figure S2A at http://ajp.amjpathol. org). Using the scoring system of Nielsen et al, ${ }^{19}$ we observed that the amount of myelin debris was significantly lower in T PLP mice than in Tova and naïve mice at 7 days post lesion (see Supplemental Figure S2B at http://ajp.amjpathol.org). Inasmuch as myelin debris is eventually cleared from the outer molecular layer after PP lesioning in naïve mice, ${ }^{42}$ we concluded that myelin-specific $T_{P L P}$-cells accelerated the clearance of myelin debris, as previously reported for $\mathrm{T}_{\mathrm{MBP}}$-cells. ${ }^{19}$

\section{Sprouting of Calretinergic Fibers Is Enhanced in $T_{P L P}$-Infiltrated Dentate Gyrus}

It has been well documented that the associational/commissural afferents from the calretinergic hilar mossy cells sprout from the inner molecular layer into the deafferented outer molecular layer after PP lesioning, which is detectable a few weeks after lesioning. ${ }^{20,23}$ Therefore, we wondered whether the sprouting of these fibers might be accelerated by myelin-specific $T$ cells, because this could contribute to explaining the increased oligodendrogenesis in the PP-lesioned $\mathrm{T}_{\mathrm{PLP}}$ recipient mice at 7 days post lesion. Comparison of the extent of the lesion-induced sprouting in $T_{P L P}$ mice, and Tova and naïve mice demonstrated that the calretinergic band in $T_{P L P}$ mice occupied $32 \%$ of the molecular layer at 7 days post lesion, which was significantly more than $28 \%$ in Tova and $27 \%$ in naïve mice at 7 days post lesion $(P<0.05$ for both groups) (Figure 5, A and B). Furthermore, in $T_{P L P}$ mice, the calretinergic band was no longer sharply demarcated, as observed in Tova and naïve mice, but was fuzzy (Figure 5A), which reflects translaminar sprouting of calretinergic fibers into the deep part of the outer molecular layer. ${ }^{23}$

Demonstrations by others that sprouting of calretinergic fibers is normally a late phenomenon ${ }^{20,23}$ would predict similarly sized calretinergic bands at the early 7 days post lesion time. Indeed, we observed that calretinergic band sizes in PP-lesioned and unlesioned naïve mice at
7 days post lesion were comparable $\left(94,700 \mu \mathrm{m}^{2}\right.$ versus $89,300 \mu \mathrm{m}^{2}$; difference not significant). The possibility of lesion-induced shrinkage of the molecular layer obscuring changes in band size in $T_{\text {PLP }}$ mice was eliminated in that lesion-induced shrinkage of the molecular layer in $\mathrm{T}_{\mathrm{PLP}}, \mathrm{T}_{\text {OVA }}$, and naïve mice was comparable $(382,100$ $\mu \mathrm{m}^{2}$ versus 326,200 $\mu \mathrm{m}^{2}$ versus 328,100 $\mu \mathrm{m}^{2}$; difference not significant for all comparisons). Considered together, the results suggested that the myelin-specific $\mathrm{T}$ cells significantly accelerated lesion-induced sprouting of calretinergic fibers into the outer molecular layer.

Because the commissural calretinergic fibers are myelinated, we investigated the myelination of the associational projections in our mice. It was observed that calretinergic fibers traversing the granule cell layer co-localized with MBP (Figure 5C), although single-labeled $\mathrm{MBP}^{+}$and calretinin ${ }^{+}$fibers were also observed. This demonstrated that at least parts of the associational fibers were myelinated.

\section{Enhanced and Prolonged TNF but Not IGF-1 or BDNF mRNA Expression in $T_{P L P}$ Mice}

Because TNF stimulates myelination, ${ }^{43}$ we investigated the production of TNF mRNA in PP-lesioned $T_{P L P}, T_{\text {OVA }}$, and naïve mice. At 2 days post lesion, $T_{P L P}$ mice demonstrated an 80-fold increase in TNF mRNA expression, which was significantly higher than the approximately 30-fold increase observed in Tova and naïve mice (Figure 6A; see also Supplemental Table S1 at http://ajp. amjpathol.org). It was remarkable that at 7 days post lesion, $T_{\text {PLP }}$ mice demonstrated a close to 100-fold increase, which was significantly higher than that in both Tova and naïve mice, which at that time had returned to close to baseline levels (Figure 6A; see also Supplemental Table S1 at http://ajp.amjpathol.org). Because both T cells and microglia and macrophages can produce $\mathrm{TNF},{ }^{44}$ we also investigated TNF mRNA expression in T cells in vitro, and observed that, compared with $\mathrm{T}_{\text {OVA }}$ mice, $T_{P L P}$ mice demonstrated higher TNF mRNA expression (Figure 6A).

We next investigated the expression of IGF-1 mRNA, which exerts trophic effects on neurons and glial cells, in particular in the OPC population. ${ }^{45,46}$ At 2 days post 
A
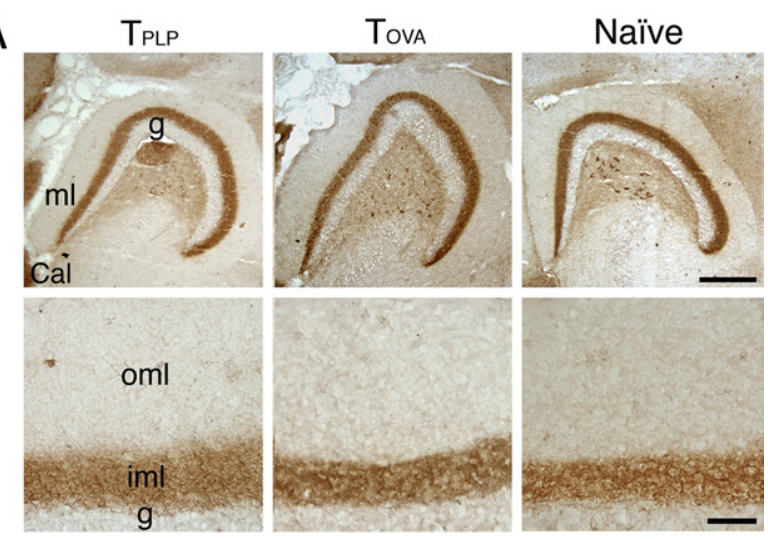

B

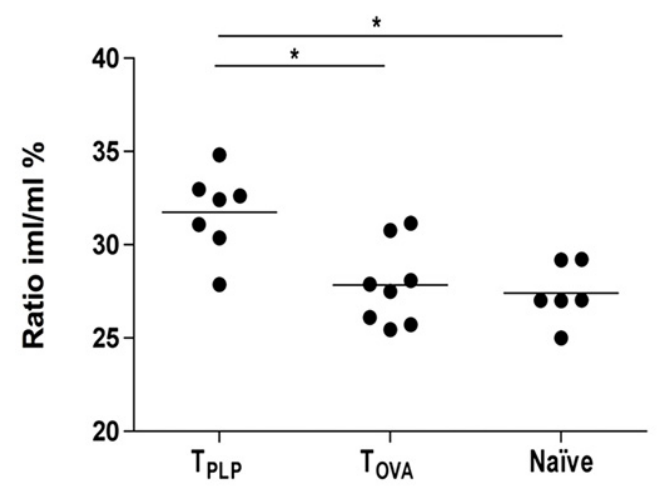

C

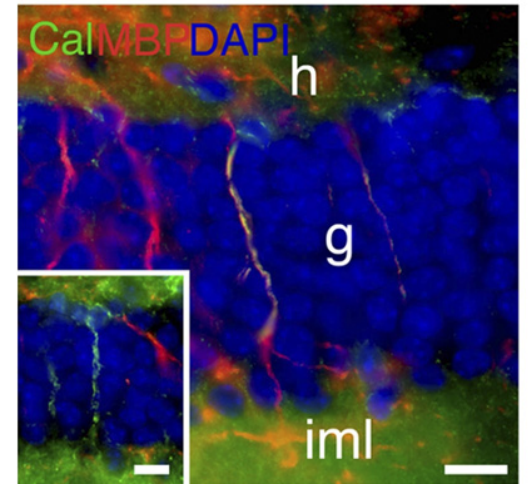

Figure 5. Enhanced lesion-induced sprouting of calretinergic fibers in $\mathrm{T}_{\mathrm{PLP}^{-}}$ infiltrated dentate gyrus. A: Calretinin staining of hilar mossy cells and their terminals at 7 days post lesion. Note in the $\mathrm{T}_{\mathrm{OVA}}$ and naïve mice the welldefined border between the inner (iml) and outer (oml) molecular layers. In $\mathrm{T}_{\mathrm{PLP}}$ mice, this border is fuzzy, reflecting calretinergic fibers sprouting from the inner molecular layer and translaminarly into the outer molecular layer. g, granule cell layer; ml, molecular layer. Scale bars: $200 \mu \mathrm{m} ; 20 \mu \mathrm{m}$ (inset) B: Area estimation demonstrates an increased inner molecular layer-molecular layer ratio in $\mathrm{T}_{\mathrm{PLP}}$ mice compared with $\mathrm{T}_{\mathrm{OVA}}$ and naïve mice at 7 days post lesion. Lines mark the mean. ${ }^{*} P<0.05$. C: Double immunofluorescence labeling for calretinin (green) and MBP (red) demonstrates co-localization of MBP to a calretinin ${ }^{+}$fiber (yellow) transversing the granule cell layer ( $g$, blue). Unmyelinated calretinin ${ }^{+}$fibers are also observed (inset). h, Hilus. Scale bars $=10 \mu \mathrm{m}$.

lesion, IGF-1 mRNA expression remained at baseline levels in $\mathrm{T}_{\mathrm{PLP}}, \mathrm{T}_{\mathrm{OVA}}$, and naïve mice (Figure 6B; see also Supplemental Table S1 at http://ajp.amjpathol.org). In contrast, at 7 days post lesion, when Tova and naïve mice demonstrated a close to twofold increase in IGF-1 mRNA expression $(P<0.01$ and $P<0.01$, respectively; see also Supplemental Table S1 at http://ajp.amjpathol.org), $T_{\text {PLP }}$ mice failed to demonstrate a lesion-induced in- crease in IGF-1 mRNA expression (Figure 6B; see also Supplemental Table S1 at http://ajp.amjpathol.org). IGF-1 mRNA was detected in $\mathrm{T}_{\mathrm{PLP}}$ and $\mathrm{T}_{\mathrm{OVA}}$ cells in vitro; however, this expression was lower than in lymph node cells from naïve mice (Figure 6B).

Inasmuch as $\mathrm{T}$ cells produce BDNF in MS lesions ${ }^{47}$ and BDNF is involved in oligodendrogenesis ${ }^{48}$ and in neuronal plasticity, ${ }^{49}$ we investigated the mRNA expression of BDNF. Although BDNF mRNA was not detected in lymph node cells from $T_{P L P}, T_{O V A}$, and naïve mice in vitro (Figure 6C), BDNF mRNA expression was readily detected in the hippocampus of $T_{P L P}$, $T_{\text {OVA }}$, and naïve mice at 2 and 7 days post lesion. However, the expression remained at the same high baseline level as in unmanipulated controls (Figure 6C; see also Supplemental Table S1 at http://ajp.amjpathol.org).

Considered together, the results indicate that TNF might have a role in the increased OPC proliferation in PP-lesioned $\mathrm{T}_{\mathrm{PLP}}$-infiltrated hippocampus.

\section{Discussion}

The major finding of this study is that CNS-infiltrating myelin-specific T cells, via increased OPC proliferation,
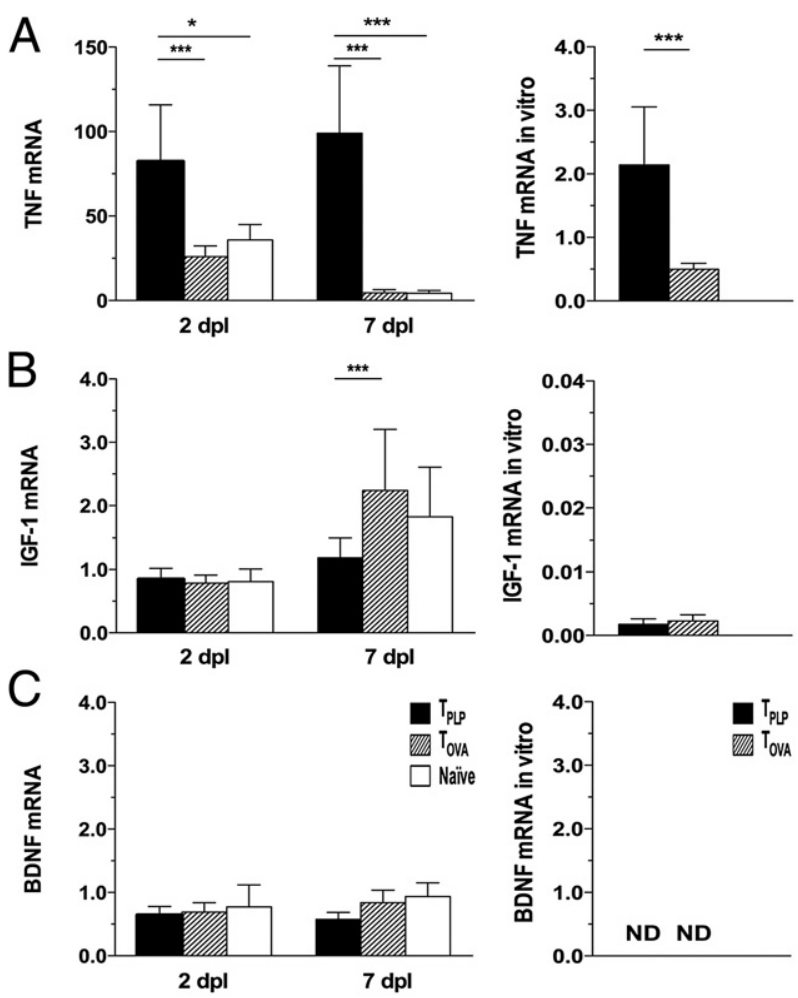

Figure 6. Enhanced expression of TNF but not IGF-1 or BDNF in $\mathrm{T}_{\mathrm{PLP}}$ mice A: TNF mRNA expression was continuously elevated in $T_{\text {PLP }}$ mice from 2 days post lesion through 7 days post lesion, compared with $\mathrm{T}_{\mathrm{OVA}}$ and naïve mice, and in vitro $\mathrm{T}_{\text {PLP }}$ cultures compared with $\mathrm{T}_{\mathrm{OVA}}$ cultures. B: IGF-1 mRNA expression demonstrated no changes at 2 days post lesion in $\mathrm{T}_{\mathrm{PLP}}$, $\mathrm{T}_{\text {OVA }}$, and naïve mice. In contrast, IGF- 1 mRNA expression was elevated in $\mathrm{T}_{\text {OVA }}$ and naïve animals at 7 days post lesion but not in PP-lesioned $\mathrm{T}_{\text {PLP }}$ mice. IGF-1 mRNA expression was low in $\mathrm{T}_{\mathrm{PLP}}$ and $\mathrm{T}_{\mathrm{OVA}}$ mice in vitro. $\mathrm{C}$ : BDNF mRNA expression showed no changes at 2 and 7 days post lesion in $\mathrm{T}_{\mathrm{PLP}}, \mathrm{T}_{\text {OVA }}$, and naïve mice. BDNF mRNA expression was not detected in vitro. ${ }^{*} P<0.05 ;{ }^{* * *} P<0.01 ;{ }^{* * * * *} P<0.001$. ND, not detected. 
stimulate adult oligodendrogenesis. The results also indicate that several different mechanisms contribute to the oligodendrotrophic effect of myelin-specific T cells.

The high mRNA expression of IFN- $\gamma$, IL-17, and IL-10 in the hippocampus of the PP-lesioned $\mathrm{T}_{\mathrm{PLP}}$ mice suggested the presence of activated Th1 and Th-17 cells, and possibly T-regs, in the mice that demonstrated the oligodendrotrophic effect. Traditionally, induction of inflammatory lesions in EAE is associated with $\mathrm{CD}^{+}{ }^{+} \mathrm{T}$ cells producing IFN- $\gamma$ and IL-17, whereas IL-10 may have a role in the recovery of EAE. ${ }^{38}$ Unlike IFN- $\gamma$ and IL-17, both of which were abundantly expressed in $\mathrm{T}_{\mathrm{PLP}}$ in vitro, the in vitro expression of IL-10 mRNA in $\mathrm{T}_{\mathrm{PLP}}$ mice was low. The observed in vivo expression of IL-10 mRNA in the PP-lesioned $T_{\text {PLP }}$ mice may reflect that IL-10 can be produced by both T cells and microglia and macrophages and that production is enhanced by both cell types via T-cell interaction. ${ }^{50} \mathrm{IL}-10$ has been associated with protection of oligodendrocytes in vitro ${ }^{51}$ and promotion of remyelination in vivo, via either enhanced oligodendrogenesis ${ }^{52}$ or enhanced clearance of myelin debris by microglia phagocytosis, ${ }^{53}$ which was observed in the present study and in previous studies. ${ }^{35}$ That we detected only low levels of IL-17 and IL-10 mRNA in the hippocampus of PP-lesioned T Ova mice despite the high levels detected in vitro likely reflects the low number of $T$ cells detected in these animals or the lack of secondary activation by specific antigen recognition. In combination, the demonstration of increased levels of mRNA levels of IFN $\gamma, I L-17$, and of IL-10 in the PP-lesioned TPLP mice and the low expression of these cytokines in the PP-lesioned T $\mathrm{TV}_{\mathrm{A}}$ mice indicates that IFN- $\gamma, \mathrm{IL}-17$, and IL-10 might contribute to the oligodendrotrophic effect of the myelin-reactive T cells.

Inflammation in MS and EAE is associated with expression of IFN- $\gamma$ by $\mathrm{CD}^{+}$and $\mathrm{CD}^{+}{ }^{+}$cells, ${ }^{54-56}$ both of which were abundant in the PP-lesioned mice receiving myelin-specific T cells. ${ }^{19}$ Whereas IFN- $\gamma$ is undetectable in the normal perfused CNS, it increases many fold during T cell-driven CNS inflammation. ${ }^{57,58}$ This is in line with our observation of absence of IFN- $\gamma$ mRNA in hippocampi from perfused unlesioned naive mice and of strongly elevated mRNA levels of IFN- $\gamma$ in $T_{\text {PLP }}$ mice. Unlike in a previous study using reverse transcription$\mathrm{PCR}^{59}$ we detected a transient increase in IFN- $\gamma$ mRNA expression in T OvA $_{\text {and }}$ aiive mice at 2 days post lesion, which declined at 7 days post lesion, corresponding to CD3 mRNA expression. However, IFN- $\gamma$ mRNA was not detectable in all mice, and the fold increase was small. Other studies have demonstrated that IFN- $\gamma$ can both inhibit differentiation and induce apoptosis of OPCs, ${ }^{60,61}$ as well as protect mature oligodendrocytes against cuprizone-induced destruction ${ }^{62}$ and inflammatory destruction, ${ }^{63}$ which suggests that the effect of IFN- $\gamma$ on the oligodendrocyte population is context-dependent. However, although our finding of a several hundred-fold increase in IFN- $\gamma$ mRNA expression in the PP-lesioned TPLP mice raises the possibility of a role for IFN- $\gamma$ in the oligodendrotrophic effect of the myelin-reactive T cells, it is noteworthy that IFN- $\gamma$ mRNA detectable via in situ hybridization was expressed by rare cells, presumed to be $T$ cells, located outside of the molecular layer of the dentate gyrus. This observation allows that $\mathrm{T}$ cell-derived factors other than IFN- $\gamma$ might stimulate oligodendrogenesis in this model.

At present, knowledge of the function of IL-17 is limited. It may have a role in, yet not be required for, development of $E A E^{64,65}$ and $M S$, inasmuch as it has been shown to be produced in T cells and astrocytes in active MS lesions. ${ }^{66}$ In the present study, we did not investigate the origin of IL-17 mRNA in the hippocampus; however, it is striking that both $T_{P L P}$ and $T_{O V A}$ mice produced high amounts of IL-17 mRNA in vitro. Furthermore, IL-17 induces TNF production in macrophages ${ }^{67}$ and enhances oligodendrocyte apoptosis in vitro, which contradicts the enhanced oligodendrogenesis observed here in vivo. However, inasmuch as a recent in vitro study demonstrated that IL-17 enhances phagocytosis by macrophages, ${ }^{68}$ it is possible that the enhanced oligodendrogenesis observed in the present study might be attributed to IL-17 stimulating microglial phagocytosis of myelin debris. It has been suggested that $\mathrm{IL}-17$ is a marker for the Th17 subset of T cells, which may exert effector function via several other mediators. ${ }^{69}$

The present study also demonstrated that myelin-specific $T$ cells stimulate sprouting of intact calretinergic fibers. In the mouse, sprouting is particularly well documented for the calretinergic axons of hilar mossy cells. ${ }^{20}$ These fibers sprout translaminarly from the inner molecular layer into the deafferented outer molecular layer after creation of a PP lesion, although normally this is not manifested until a few weeks after PP lesioning. ${ }^{23}$ Unlike the unmyelinated cholinergic septo-hippocampal afferents that also sprout after creation of a PP lesion, ${ }^{70}$ the present study demonstrates that at least part of the calretinergic fibers, presumably associational fibers, that traverse the granule cell layer are myelinated. This adds to observations by others that demonstrated that the commissural calretinergic fibers are myelinated. ${ }^{22}$ Our observation of an increased sprouting response of calretinergic fibers from the inner molecular layer into the deafferented outer molecular layer at 7 days post lesion in the $T_{P L P}$ mice, but not in the $T_{\text {OVA }}$ and naïve mice, correlates well with the translaminar sprouting usually observed several weeks after PP lesioning. ${ }^{23}$ Inasmuch as ultrastructural studies have suggested that the process of axonal elongation is usually first initiated at 4 to 6 days post lesion and completed after 12 days post lesion, ${ }^{21,71}$ it seems likely that the myelin-specific $T$ cells accelerated the sprouting of the calretinergic fibers. Given our recent demonstration of adult oligodendrogenesis in areas of axonal sprouting in non-deafferented zones of the hippocampus of PP-lesioned mice, ${ }^{24}$ the accelerated sprouting of the calretinergic fibers might itself stimulate oligodendrogenesis. Furthermore, we observed that myelin-specific $T_{P L P}$ cells enhanced the clearance of myelin debris, probably due to stimulation of microglial macrophage myelin phagocytosis, as we have previously reported for myelin-specific $\mathrm{T}_{\mathrm{MBP}}$ cells. ${ }^{35} \mathrm{Be}-$ cause myelin debris is a potent inhibitor of axonal outgrowth, ${ }^{72-74}$ axonal sprouting may be additionally stimulated by the accelerated removal of myelin debris, 
making the neural tissue more permissive to the axonal sprouts. ${ }^{72-74}$ Furthermore, myelin debris itself inhibits remyelination via inhibition of OPC differentiation. ${ }^{74,75}$

The results show that the increase in oligodendrogenesis is linked to increased proliferation of the $\mathrm{NG}^{+} \mathrm{OPC}$ population and to morphologic changes specific to the $T_{P L P}$ mice. Although proliferation is a characteristic feature of OPC activation, ${ }^{14,16,76}$ these cells also respond by changing their structure and level of expression of NG2. Morphologic changes have been reported to be characteristic of the OPC response to inflammation, ${ }^{77}$ and may have been exaggerated by the abundance of activated myelin-specific T cells in the dentate gyrus in T TLP mice. Recently, it has become clear that $\mathrm{NG}^{+}$cells form classic synapses with cortical neurons ${ }^{78}$ and that neurons, via axon collaterals, co-activate NG2 cells along with their postsynaptic neurons. ${ }^{79-81}$ In principle, integration of $\mathrm{NG}_{2}{ }^{+}$cells in the axonal circuitry places the $\mathrm{NG}_{2}{ }^{+}$cells in a unique position to sense the disappearance of presynaptic input, because it occurs in the outer molecular layer after PP lesion, and to sense stimuli from even single sprouting axons. Furthermore, there is evidence that synaptic mechanisms modulate both division and migration of NG2 cells. ${ }^{82,83}$ These findings correlate well with the observation of division of $\mathrm{NG}^{+}{ }^{+}$cells in areas of axonal sprouting in the non-deafferented hippocampus, which results in an increased number of oligodendrocytes and length of myelinated fibers several weeks after PP lesioning. ${ }^{24}$ Although we observed a few $\mathrm{BrdU}^{+} \mathrm{CNP}^{+}$ cells extending processes toward $\mathrm{CNP}^{+}$myelinated fibers, suggestive of myelination, a thorough study of myelination of sprouting axons would require an extended survival time. ${ }^{21,71}$

In line with studies that have demonstrated that autoimmune infiltration can exert beneficial effects on injured neurons, ${ }^{47,84}$ we report here that infiltration with myelinspecific $T$ cells can stimulate proliferation and differentiation of OPCs. Our observations also raise the possibility that several different mechanisms contribute to the oligodendrotrophic effect of myelin-specific T cells. In addition to IFN- $\gamma$, subpopulations of T cells in inflammatory lesions produce BDNF, ${ }^{84-86}$ which in addition to its multiple beneficial effects on neurons ${ }^{87}$ is a potent stimulus of remyelination ${ }^{88}$ and neuronal plasticity. ${ }^{49}$ That we did not detect BDNF mRNA expression in vitro suggests that BDNF in vivo is produced by CNS neurons and glial cells, which is in line with in situ hybridization studies that demonstrated high BDNF mRNA expression, in particular in hippocampal neurons. ${ }^{89}$ After PP lesioning, transient upregulation in $\mathrm{mRNA}$ expression has been observed in the granular neurons. ${ }^{90,91}$ It is, therefore, possible that the unchanged mRNA levels observed in TPLP mice may be the result of a dilution bias because GPCR performed on the entire hippocampus, as in the present study, might underestimate the lesion-induced local changes in cellular mRNA expression. It is noteworthy that hippocampal sprouting after injury does not seem to depend on BDNF. ${ }^{92,93}$

TNF induces injury to both oligodendrocytes and myelin ${ }^{43,94,95}$ and promotes OPC differentiation and remyelination. ${ }^{43}$ In the CNS, TNF is expressed primarily by microglia or infiltrating macrophages in response to injury, ${ }^{96}$ and is induced by inflammatory cytokines such as IFN- $\gamma^{97}$ or by cell-cell contact with activated myelin-reactive T cells. ${ }^{98,99}$ Using the PP lesion model, our group has previously demonstrated a transient increase in TNF mRNA expression levels at 2 days post lesion, ${ }^{34}$ which was increased by the presence of IFN- $\gamma .{ }^{100}$ This was confirmed in the present study, in which a marked increase in TNF mRNA expression was observed in TPLP mice at 2 days post lesion and persisted at 7 days post lesion. Microglial production of TNF has been previously associated with increased phagocytosis of myelin debris in microglia in vitro. ${ }^{101,102}$ As reported for IL-10 mRNA, the elevated TNF mRNA expression was concurrent with enhanced clearance of myelin debris, which has previously been attributed to microglial phagocytosis in PPlesioned $\mathrm{T}_{\text {MBP }}$ mice. $^{35}$

Although we were not able to detect any changes in IGF-1 mRNA expression at the time of maximal OPC proliferation at 2 days post lesion, as much as twofold up-regulation in $\mathrm{T}_{\text {Ova }}$ and naîve mice was observed at 7 days post lesion. This corresponds well to in situ hybridization results that demonstrated elevated IGF-1 mRNA expression in the deafferented outer molecular layer up to 12 days post lesion in rats. ${ }^{46,103}$ IGF- 1 is expressed in glial cells and neurons in normal CNS. ${ }^{104,105}$ As mentioned for BDNF, the inability to detect a T cell-mediated effect on IGF-1 mRNA expression at 2 and 7 days post lesion in $T_{P L P}$ mice could also be due to dilution bias. An effect of the myelin-specific T cells on IGF-1 signaling in OPCs could also be accomplished by up-regulation of bindings sites on target cells, as has been demonstrated for IGF-1 binding sites after PP lesioning. ${ }^{106}$ Thus, T cells might stimulate oligodendrogenesis through lesion-reactive microglia by different mechanisms, and a role for BDNF and IGF-1 cannot be excluded by our findings. This was recently exemplified by IFN- $\gamma$-stimulated microglia that demonstrated a phenotype alternately beneficial or detrimental to formation of oligodendrocytes, depending on co-expression of other cytokines. ${ }^{107}$ Thus, cytokines produced by subpopulations of $T$ cells may have far more wide-ranging effects within the neural tissue than has been predicted.

In conclusion, findings of the present study demonstrate that myelin-specific T cells can stimulate OPC proliferation and oligodendrogenesis in vivo. Inasmuch as most of the current therapeutic strategies for MS are immunomodulatory, these findings are of importance not only for understanding T cell-mediated effects in MS but also for future refinement of therapeutic strategies.

\section{Acknowledgments}

We thank Lene Jørgensen and Sussanne Petersen for technical assistance, Karsten Skjødt for assistance in biotinylating the CNP antibody, and the European Cooperation in Science and Technology (COST) Action BM0603 Inflammation in Brain Disease (NEURINFNET) for discussions and for networking support. 


\section{References}

1. Weiner HL: Multiple sclerosis is an inflammatory T-cell-mediated autoimmune disease. Arch Neurol 2004, 61:1613-1615

2. Lucchinetti C, Brück W, Parisi J, Scheithauer B, Rodriguez M, Lassmann $\mathrm{H}$ : Heterogeneity of multiple sclerosis lesions: implications for the pathogenesis of demyelination. Ann Neurol 2000, 47:707-717

3. Wolswijk G: Oligodendrocyte precursor cells in the demyelinated multiple sclerosis spinal cord. Brain 2002, 125:338-349

4. Raine CS, Wu E: Multiple sclerosis: remyelination in acute lesions. J Neuropathol Exp Neurol 1993, 52:199-204

5. Dawson MR, Polito A, Levine JM, Reynolds R: NG2-expressing glial progenitor cells: an abundant and widespread population of cycling cells in the adult rat CNS. Mol Cell Neurosci 2003, 24:476-488

6. French-Constant C, Raff MC: Proliferating bipotential glial progenitor cells in adult rat optic nerve. Nature 1986, 319:499-502

7. Blakemore WF, Franklin RJ: Remyelination in experimental models of toxin-induced demyelination. Curr Topic Microbiol Immunol 2008, 318:193-212

8. Levine JM, Reynolds R: Activation and proliferation of endogenous oligodendrocyte precursor cells during ethidium bromide-induced demyelination. Exp Neurol 1999, 160:333-347

9. Reynolds R, Dawson M, Papadopoulos D, Polito A, Di Bello IC, Pham-Dinh D, Levine J: The response of NG2-expressing oligodendrocyte progenitors to demyelination in MOG-EAE and MS. J Neurocytol 2002, 31:523-536

10. Matsumoto H, Kumon Y, Watanabe H, Ohnishi T, Shudou M, Chuai M, Imai Y, Takahashi H, Tanaka J: Accumulation of macrophage-like cells expressing NG2 proteoglycan and Iba1 in ischemic core of rat brain after transient middle cerebral artery occlusion. J Cereb Blood Flow Metab 2008, 28:149-163

11. Jones LL, Sajed D, Tuszynski MH: Axonal regeneration through regions of chondroitin sulfate proteoglycan deposition after spinal cord injury: a balance of permissiveness and inhibition. $J$ Neurosci 2003, 23:9276-9288

12. Lytle JM, Vicini S, Wrathall JR: Phenotypic changes in NG2+ cells after spinal cord injury. J Neurotrauma 2006, 23:1726-1738

13. Dehn D, Burbach GJ, Schafer R, Deller T: NG2 upregulation in the denervated rat fascia dentata following unilateral entorhinal cortex Iesion. Glia 2006, 53:491-500

14. Nielsen $\mathrm{HH}$, Ladeby $\mathrm{R}$, Drojdahl N, Peterson AC, Finsen B: Axonal degeneration stimulates the formation of NG2+ cells and oligodendrocytes in the mouse. Glia 2006, 54:105-115

15. Schonberg DL, Popovich PG, McTigue DM: Oligodendrocyte generation is differentially influenced by toll-like receptor (TLR) 2 and TLR4-mediated intraspinal macrophage activation. J Neuropathol Exp Neurol 2007, 66:1124-1135

16. Dawson MR, Levine JM, Reynolds R: NG2-expressing cells in the central nervous system: are they oligodendroglial progenitors? J Neurosci Res 2000, 61:471-479

17. Jensen MB, Gonzalez B, Castellano B, Zimmer J: Microglial and astroglial reactions to anterograde axonal degeneration: a histochemical and immunocytochemical study of the adult rat fascia dentata after entorhinal perforant path lesions. Exp Brain Res 1994 98:245-260

18. Kwidzinski E, Mutlu LK, Kovac AD, Bunse J, Goldmann J, Mahlo J, Aktas O, Zipp F, Kamradt T, Nitsch R, Bechmann I: Self-tolerance in the immune privileged CNS: lessons from the entorhinal cortex lesion model. J Neural Transm Suppl 2003, -4929

19. Nielsen $H H$, Ladeby $R$, Fenger $C$, Toft-Hansen $H$, Babcock AA, Owens T, Finsen B: Enhanced microglia clearance of myelin debris in T-cell infiltrated central nervous system. J Neuropathol Exp Neurol 2009, 68:845-856

20. Phinney AL, Calhoun ME, Woods AG, Deller T, Jucker M: Stereological analysis of the reorganization of the dentate gyrus following entorhinal cortex lesion in mice. Eur J Neurosci 2004, 19:1731-1740

21. Steward O, Vinsant SL: The process of reinnervation in the dentate gyrus of adult rats: a quantitative electron microscopic analysis of terminal proliferation and reactive synaptogenesis. J Comp Neurol 1983, 214:370-386

22. Blasco-Ibanez JM, Freund TF: Distribution, ultrastructure, and connectivity of calretinin-immunoreactive mossy cells of the mouse dentate gyrus. Hippocampus 1997, 7:307-320
23. Del Turco D, Woods AG, Gebhardt C, Phinney AL, Jucker M, Frotscher M, Deller T: Comparison of commissural sprouting in the mouse and rat fascia dentata after entorhinal cortex lesion. Hippocampus 2003, 13:685-699

24. Drojdahl N, Nielsen HH, Gardi JE, Wree A, Peterson AC, Nyengaard JR, Eyer J, Finsen B: Axonal plasticity elicits long-term changes in oligodendroglia and myelinated fibers. Glia 2010, 58:29-42

25. Patrikios $P$, Stadelmann C, Kutzelnigg A, Rauschka H, Schmidbauer M, Laursen H, Sorensen PS, Bruck W, Lucchinetti C, Lassmann H: Remyelination is extensive in a subset of multiple sclerosis patients. Brain 2006, 129:3165-3172

26. Ludwin SK: Chronic demyelination inhibits remyelination in the central nervous system: an analysis of contributing factors. Lab Invest 1980, 43:382-387

27. Niehaus A, Shi J, Grzenkowski M, Diers-Fenger M, Archelos J, Hartung HP, Toyka K, Bruck W, Trotter J: Patients with active relapsing-remitting multiple sclerosis synthesize antibodies recognizing oligodendrocyte progenitor cell surface protein: implications for remyelination. Ann Neurol 2000, 48:362-371

28. Krakowski ML, Owens T: Naïve T lymphocytes traffic to inflamed central nervous system, but require antigen recognition for activation. Eur J Immunol 2000, 30:1002-1009

29. Flugel A, Berkowicz T, Ritter T, Labeur M, Jenne DE, Li Z, Ellwart JW, Willem M, Lassmann $\mathrm{H}$, Wekerle $\mathrm{H}$ : Migratory activity and functional changes of green fluorescent effector cells before and during experimental autoimmune encephalomyelitis. Immunity 2001, 14:547-560

30. Dissing-Olesen L, Ladeby R, Nielsen HH, Toft-Hansen H, Dalmau I, Finsen B: Axonal lesion-induced microglial proliferation and microglial cluster formation in the mouse. Neuroscience 2007, 149:112-122

31. Matthews DA, Cotman C, Lynch G: An electron microscopic study of lesion-induced synaptogenesis in the dentate gyrus of the adult rat. I: Magnitude and time course of degeneration. Brain Res 1976, 115:1-21

32. Friedman B, Hockfield S, Black JA, Woodruff KA, Waxman SG: In situ demonstration of mature oligodendrocytes and their processes: an immunocytochemical study with a new monoclonal antibody, Rip. Glia 1989, 2:380-390

33. Watanabe M, Sakurai Y, Ichinose T, Aikawa Y, Kotani M, Itoh K Monoclonal antibody Rip specifically recognizes 2 ', $3^{\prime}$-cyclic nucleotide $3^{\prime}$-phosphodiesterase in oligodendrocytes. J Neurosci Res 2006, 84:525-533

34. Fenger C, Drojdahl N, Wirenfeldt M, Sylvest L, Jorgensen OS Meldgaard M, Lambertsen KL, Finsen B: Tumor necrosis factor and its p55 and p75 receptors are not required for axonal lesion-induced microgliosis in mouse fascia dentata. Glia 2006, 54:591-605

35. Nielsen $H H$, Ladeby $R$, Fenger $C$, Toft-Hansen $H$, Babcock AA Owens T, Finsen B: Enhanced microglial clearance of myelin debris in T cell-infiltrated central nervous system. J Neuropathol Exp Neurol 2009, 68:845-856

36. Meldgaard M, Fenger C, Lambertsen KL, Pedersen MD, Ladeby R Finsen $B$ : Validation of two reference genes for mRNA level studies of murine disease models in neurobiology. J Neurosci Methods 2006, 156:101-110

37. Lambertsen KL, Gregersen R, Meldgaard M, Clausen BH, Heibol EK, Ladeby R, Knudsen J, Frandsen A, Owens T, Finsen B: A role for interferon-gamma in focal cerebral ischemia in mice. $J$ Neuropathol Exp Neurol 2004, 63:942-955

38. Kennedy MK, Torrance DS, Picha KS, Mohler KM: Analysis of cytokine mRNA expression in the central nervous system of mice with experimental autoimmune encephalomyelitis reveals that $\mathrm{IL}-10$ mRNA expression correlates with recovery. J Immunol 1992, 149: 2496-2505

39. Trotter J, Karram K, Nishiyama A: NG2 cells: properties, progeny and origin. Brain Res Rev 2010, 63:72-82

40. Levison SW, Young GM, Goldman JE: Cycling cells in the adult rat neocortex preferentially generate oligodendroglia. J Neurosci Res 1999, 57:435-446

41. Jensen MB, Hegelund IV, Poulsen FR, Owens T, Zimmer J, Finsen B: Microglial reactivity correlates to the density and the myelination of the anterogradely degenerating axons and terminals following perforant path denervation of the mouse fascia dentata. Neuroscience 1999, 93:507-518 
42. Buss A, Schwab ME: Sequential loss of myelin proteins during Wallerian degeneration in the rat spinal cord. Glia 2003, 42:424-432

43. Arnett HA, Mason J, Marino M, Suzuki K, Matsushima GK, Ting JP. TNF alpha promotes proliferation of oligodendrocyte progenitors and remyelination. Nat Neurosci 2001, 4:1116-1122

44. Lambertsen KL, Meldgaard M, Ladeby R, Finsen B: A quantitative study of microglial-macrophage synthesis of tumor necrosis factor during acute and late focal cerebral ischemia in mice. J Cereb Blood Flow Metab 2005, 25:119-135

45. Mason JL, Goldman JE: A2B5+ and O4+ cycling progenitors in the adult forebrain white matter respond differentially to PDGF-AA, FGF-2, and IGF-1. Mol Cell Neurosci 2002, 20:30-42

46. Guthrie KM, Nguyen T, Gall CM: Insulin-like growth factor-1 mRNA is increased in deafferented hippocampus: spatiotemporal correspondence of a trophic event with axon sprouting. J Comp Neurol 1995, 352:147-160

47. Stadelmann C, Kerschensteiner M, Misgeld T, Brück W, Hohlfeld R, Lassmann $\mathrm{H}$ : BDNF and gp145trkB in multiple sclerosis brain lesions: neuroprotective interactions between immune and neuronal cells? Brain 2002, 125:75-85

48. McTigue DM, Horner PJ, Stokes BT, Gage FH: Neurotrophin-3 and brain-derived neurotrophic factor induce oligodendrocyte proliferation and myelination of regenerating axons in the contused adult rat spinal cord. J Neurosci 1998, 18:5354-5365

49. Ramer MS: Endogenous neurotrophins and plasticity following spinal deafferentiation. Exp Neurol 2010, doi:10.1016/j.expneurol.2010.12.021

50. Chabot S, Williams G, Hamilton M, Sutherland G, Yong VW: Mechanisms of IL-10 production in human microglia-T cell interaction. J Immunol 1999, 162:6819-6828

51. Broderick C, Duncan L, Taylor N, Dick AD: IFN-gamma and LPSmediated IL-10-dependent suppression of retinal microglial activation. Invest Ophthalmol Vis Sci 2000, 41:2613-2622

52. Yang J, Jiang Z, Fitzgerald DC, Ma C, Yu S, Li H, Zhao Z, Li Y, Ciric B, Curtis M, Rostami A, Zhang GX: Adult neural stem cells expressing $\mathrm{IL}-10$ confer potent immunomodulation and remyelination in experimental autoimmune encephalitis. J Clin Invest 2009, 119: 3678-3691

53. Smith ME, van der Maesen K, Somera FP: Macrophage and microglial responses to cytokines in vitro: phagocytic activity, proteolytic enzyme release, and free radical production. J Neurosci Res 1998, 54:68-78

54. Liblau RS, Singer SM, McDevitt HO: Th1 and Th2 CD4+ T cells in the pathogenesis of organ-specific autoimmune diseases. Immunol Today $1995,16: 34-38$

55. Zamvil S, Nelson P, Trotter J, Mitchell D, Knobler R, Fritz R, Steinman $\mathrm{L}$ : T-cell clones specific for myelin basic protein induce chronic relapsing paralysis and demyelination. Nature 1985, 317:355-358

56. Goverman J: Autoimmune T cell responses in the central nervous system. Nat Rev Immunol 2009, 9:393-407

57. Popko B, Corbin JG, Baerwald KD, Dupree J, Garcia AM: The effects of interferon-gamma on the central nervous system. Mol Neurobiol 1997, 14:19-35

58. Imitola J, Chitnis T, Khoury SJ: Cytokines in multiple sclerosis: from bench to bedside. Pharmacol Ther 2005, 106:163-177

59. Jensen MB, Poulsen FR, Finsen B: Axonal sprouting regulates myelin basic protein gene expression in denervated mouse hippocampus. Int J Dev Neurosci 2000, 18:221-235

60. Chew LJ, King WC, Kennedy A, Gallo V: Interferon-gamma inhibits cell cycle exit in differentiating oligodendrocyte progenitor cells. Glia 2005, 52:127-143

61. Lin W, Kemper A, Dupree JL, Harding HP, Ron D, Popko B: Interferon-gamma inhibits central nervous system remyelination through a process modulated by endoplasmic reticulum stress. Brain 2006, 129:1306-1318

62. Gao X, Gillig TA, Ye P, D'Ercole AJ, Matsushima GK, Popko B: Interferon-gamma protects against cuprizone-induced demyelination. Mol Cell Neurosci 2000, 16:338-349

63. Lin W, Bailey SL, Ho H, Harding HP, Ron D, Miller SD, Popko B: The integrated stress response prevents demyelination by protecting oligodendrocytes against immune-mediated damage. J Clin Invest 2007, 117:448-456
64. Haak S, Croxford AL, Kreymborg K, Heppner FL, Pouly S, Becher B Waisman A: IL-17A and IL-17F do not contribute vitally to autoimmune neuro-inflammation in mice. J Clin Invest 2009, 119:61-69

65. Park $\mathrm{H}$, Li Z, Yang $X O$, Chang $S H$, Nurieva R, Wang $Y H$, Wang $Y$, Hood L, Zhu Z, Tian Q, Dong C: A distinct lineage of CD4 T cells regulates tissue inflammation by producing interleukin 17. Nat Immunol 2005, 6:1133-1141

66. Tzartos JS, Friese MA, Craner MJ, Palace J, Newcombe J, Esiri MM Fugger L: Interleukin-17 production in central nervous system-infiltrating $T$ cells and glial cells is associated with active disease in multiple sclerosis. Am J Pathol 2008, 172:146-155

67. Jovanovic DV, Di Battista JA, Martel-Pelletier J, Jolicoeur FC, He Y, Zhang M, Mineau F, Pelletier JP: IL-17 stimulates the production and expression of proinflammatory cytokines, IL-beta and TNF-alpha, by human macrophages. J Immunol 1998, 160:3513-3521

68. Silverpil E, Glader P, Hansson M, Linden A: Impact of interleukin-17 on macrophage phagocytosis of apoptotic neutrophils and particles. Inflammation 34:1-9

69. Codarri L, Gyulveszi G, Tosevski V, Hesske L, Fontana A, Magnenat $L$, Suter T, Becher B: ROR $\gamma$ t drives production of the cytokine GM-CSF in helper T cells, which is essential for the effector phase of autoimmune neuroinflammation. Nat Immunol 2011, 12:560-567

70. Stanfield BB, Cowan WM: The sprouting of septal afferents to the dentate gyrus after lesions of the entorhinal cortex in adult rats. Brain Res 1982, 232:162-170

71. Meier S, Brauer AU, Heimrich B, Nitsch R, Savaskan NE: Myelination in the hippocampus during development and following lesion. Cell Mol Life Sci 2004, 61:1082-1094

72. Schwab ME: Nogo and axon regeneration. Curr Opin Neurobiol 2004, 14:118-124

73. McPhail LT, Borisoff JF, Tsang B, Hwi LP, Kwiecien JM, Ramer MS Protracted myelin clearance hinders central primary afferent regeneration following dorsal rhizotomy and delayed neurotrophin-3 treatment. Neurosci Lett 2007, 411:206-211

74. Schwab ME: Myelin-associated inhibitors of neurite growth and regeneration in the CNS. Trends Neurosci 1990, 13:452-456

75. Kotter MR, Li WW, Zhao C, Franklin RJ: Myelin impairs CNS remyelination by inhibiting oligodendrocyte precursor cell differentiation. J Neurosci 2006, 26:328-332

76. Blakemore WF: Regeneration and repair in multiple sclerosis: the view of experimental pathology. J Neurol Sci 2008, 265:1-4

77. Di Bello IC, Dawson MR, Levine JM, Reynolds R: Generation of oligodendroglial progenitors in acute inflammatory demyelinating lesions of the rat brain stem is associated with demyelination rather than inflammation. J Neurocytol 1999, 28:365-381

78. Gallo V, Mangin JM, Kukley M, Dietrich D: Synapses on NG2 expressing progenitors in the brain: multiple functions?. J Physiol 2008, 586:3767-3781

79. Bergles DE, Roberts JD, Somogyi P, Jahr CE: Glutamatergic synapses on oligodendrocyte precursor cells in the hippocampus. Nature 2000, 405:187-191

80. Mangin JM, Kunze A, Chittajallu R, Gallo V: Satellite NG2 progenitor cells share common glutamatergic inputs with associated interneu rons in the mouse dentate gyrus. J Neurosci 2008, 28:7610-7623

81. Muller J, Reyes-Haro D, Pivneva T, Nolte C, Schaette R, Lubke J Kettenmann $\mathrm{H}$ : The principal neurons of the medial nucleus of the trapezoid body and $\mathrm{NG2}(+)$ glial cells receive coordinated excitatory synaptic input. J Gen Physiol 2009, 134:115-127

82. Yuan X, Eisen AM, McBain CJ, Gallo V: A role for glutamate and its receptors in the regulation of oligodendrocyte development in cerebellar tissue slices. Development 1998, 125:2901-2914

83. Tong XP, Li XY, Zhou B, Shen W, Zhang ZJ, Xu TL, Duan S: Ca(2+) signaling evoked by activation of $\mathrm{Na}(+)$ channels and $\mathrm{Na}(+) /$ $\mathrm{Ca}(2+)$ exchangers is required for GABA-induced NG2 cell migration. J Cell Biol 2009, 186:113-128

84. Hammarberg H, Lidman O, Lundberg C, Eltayeb SY, Gielen AW Muhallab S, Svenningsson A, Linda H, van Der Meide PH, Cullheim S, Olsson T, Piehl F: Neuroprotection by encephalomyelitis: rescue of mechanically injured neurons and neurotrophin production by CNS-infiltrating T and natural killer cells. J Neurosci 2000, 20:52835291

85. Besser M, Wank R: Cutting edge: clonally restricted production of the neurotrophins brain-derived neurotrophic factor and neurotro- 
phin-3 mRNA by human immune cells and Th1/Th2-polarized expression of their receptors. J Immunol 1999, 162:6303-6306

86. Kerschensteiner M, Gallmeier E, Behrens L, Leal VV, Misgeld T, Klinkert WE, Kolbeck R, Hoppe E, Oropeza-Wekerle RL, Bartke I, Stadelmann C, Lassmann H, Wekerle H, Hohlfeld R: Activated human $T$ cells, $B$ cells, and monocytes produce brain-derived neurotrophic factor in vitro and in inflammatory brain lesions: a neuroprotective role of inflammation? J Exp Med 1999, 189:865-870

87. Chao MV: Neurotrophins and their receptors: a convergence point for many signalling pathways. Nat Rev Neurosci 2003, 4:299-309

88. Linker RA, Lee DH, Demir S, Wiese S, Kruse N, Siglienti I, Gerhardt E, Neumann H, Sendtner M, Luhder F, Gold R: Functional role of brain-derived neurotrophic factor in neuroprotective autoimmunity: therapeutic implications in a model of multiple sclerosis. Brain 2010, 133:2248-2263

89. Hofer M, Pagliusi SR, Hohn A, Leibrock J, Barde YA: Regional distribution of brain-derived neurotrophic factor mRNA in the adult mouse brain. EMBO J 1990, 9:2459-2464

90. Burbach GJ, Dehn D, Del Turco D, Deller T: Quantification of layerspecific gene expression in the hippocampus: effective use of laser microdissection in combination with quantitative RT-PCR. J Neurosci Methods 2003, 131:83-91

91. Lapchak PA, Araujo DM, Hefti F: BDNF and trkB mRNA expression in the rat hippocampus following entorhinal cortex lesions. Neuroreport 1993, 4:191-194

92. Forster E, Naumann T, Deller T, Straube A, Nitsch R, Frotscher M: Cholinergic sprouting in the rat fascia dentata after entorhinal lesion is not linked to early changes in neurotrophin messenger RNA expression. Neuroscience 1997, 80:731-739

93. Bender R, Heimrich B, Meyer M, Frotscher M: Hippocampal mossy fiber sprouting is not impaired in brain-derived neurotrophic factordeficient mice. Exp Brain Res 1998, 120:399-402

94. Cammer W: Effects of TNFalpha on immature and mature oligodendrocytes and their progenitors in vitro. Brain Res 2000, 864:213-219

95. Taupin V, Renno T, Bourbonniere L, Peterson AC, Rodriguez M, Owens $\mathrm{T}$ : Increased severity of experimental autoimmune encephalomyelitis, chronic macrophage/microglial reactivity, and demyelination in transgenic mice producing tumor necrosis factor-alpha in the central nervous system. Eur J Immunol 1997, 27:905-913

96. Gregersen R, Lambertsen K, Finsen B: Microglia and macrophages are the major source of tumor necrosis factor in permanent middle cerebral artery occlusion in mice. J Cereb Blood Flow Metab 2000, 20:53-65

97. Renno T, Krakowski M, Piccirillo C, Lin JY, Owens T: TNF-alpha expression by resident microglia and infiltrating leukocytes in the central nervous system of mice with experimental allergic encephalomyelitis: regulation by Th1 cytokines. J Immunol 1995 154:944-953

98. Chabot S, Williams G, Yong VW: Microglial production of TNF-alpha is induced by activated T lymphocytes: involvement of VLA-4 and inhibition by interferonbeta-1b. J Clin Invest 1997, 100:604-612

99. Dasgupta S, Jana M, Liu X, Pahan K: Role of very-late antigen-4 (VLA-4) in myelin basic protein-primed T cell contact-induced expression of proinflammatory cytokines in microglial cells. J Biol Chem 2003, 278:22424-22431

100. Jensen MB, Hegelund IV, Lomholt ND, Finsen B, Owens T: IFNgamma enhances microglial reactions to hippocampal axonal degeneration. J Neurosci 2000, 20:3612-3621

101. Bruck W, Bruck Y, Friede RL: TNF-alpha suppresses CR3-mediated myelin removal by macrophages. J Neuroimmunol 1992, 38:9-17

102. Smith ME: Phagocytic properties of microglia in vitro: implications for a role in multiple sclerosis and EAE. Microsc Res Tech 2001 54:81-94

103. Woods AG, Guthrie KM, Kurlawalla MA, Gall CM: Deafferentiationinduced increases in hippocampal insulin-like growth factor-1 messenger RNA expression are severely attenuated in middle aged and aged rats. Neuroscience 1998, 83:663-668

104. Valenzuela CF, Kazlauskas A, Weiner JL: Roles of platelet-derived growth factor in the developing and mature nervous systems. Brain Res Brain Res Rev 1997, 24:77-89

105. Chesik D, De Keyser J, Wilczak N: Insulin-like growth factor system regulates oligodendroglial cell behavior: therapeutic potential in CNS. J Mol Neurosci 2008, 35:81-90

106. Kar S, Baccichet A, Quirion R, Poirier J: Entorhinal cortex lesion induces differential responses in [125I]insulin-like growth factor I, [125I]insulin-like growth factor II and [125I]insulin receptor binding sites in the rat hippocampal formation. Neuroscience 1993, 55: $69-80$

107. Butovsky O, Ziv Y, Schwartz A, Landa G, Talpalar AE, Pluchino S, Martino G, Schwartz M: Microglia activated by IL-4 or IFN-gamma differentially induce neurogenesis and oligodendrogenesis from adult stem/progenitor cells. Mol Cell Neurosci 2006, 31:149-160 